\title{
Inventory models for managing deteriorating products: a literature review
}

\author{
Freddy Perez ${ }^{1}$ and Fidel Torres ${ }^{2}$ \\ ${ }^{1}$ Universidad de la Costa \\ ${ }^{2}$ Universidad de los Andes
}

May 29, 2020

\begin{abstract}
The problem of determining the economic order quantity has long attracted the attention of researchers, and several models have been developed to meet requirements under different circumstances at minimum cost. In the present paper, we conduct a structural content analysis of 317 selected peer-reviewed research articles that were published during the period 2001-2018 and ranked with a quartile score of Q1 by either ISI or Scopus database. By discussing the main topics of the inventory modeling literature, we provide a comprehensive view of the past research dealing with the management of deteriorating items. Here, we focus on items undergoing physical modification during the planning period, which encompasses a wide variety of products such as fresh produce, processed food, pharmaceuticals and blood products. Therefore, based on our holistic analysis, we identify new trends and we highlights crucial research opportunities to develop more comprehensive and practical models.
\end{abstract}

Informative title

Inventory models for managing deteriorating products: a literature review

Running title

Deteriorating inventory models: a review

Full names of authors

Freddy Andrés Pérez Mantilla

José Fidel Torres Delgado

Author's institutional affiliations

Freddy Pérez (ORCID 0000-0002-2456-3268), PhD., Associated Professor, Universidad de la Costa, Barranquilla, Colombia (fperez23@cuc.edu.co).

Fidel Torres (0000-0001-7379-6212), PhD., Associated Professor, Universidad de los Andes, Bogotá, Colombia (ftorres@uniandes.edu.co).

Acknowledgments

We thank Caitlin Simpson May and Diego Castiblanco, from Universidad de los Andes, for editing a draft of this manuscript.

Abstract and keywords

The problem of determining the economic order quantity has long attracted the attention of researchers, and several models have been developed to meet requirements under different circumstances at minimum 
cost. In the present paper, we conduct a structural content analysis of 317 selected peer-reviewed research articles that were published during the period 2001-2018 and ranked with a quartile score of Q1 by either ISI or Scopus database. By discussing the main topics of the inventory modeling literature, we provide a comprehensive view of the past research dealing with the management of deteriorating items. Here, we focus on items undergoing physical modification during the planning period, which encompasses a wide variety of products such as fresh produce, processed food, pharmaceuticals and blood products. Therefore, based on our holistic analysis, we identify new trends and we highlights crucial research opportunities to develop more comprehensive and practical models.

Keywords: inventory models, deteriorating inventory, perishability, shelf life, review.

Main text

\section{Introduction}

Inventory management is one of the most fundamental and challenging activities for any company dealing with raw materials, work-in-process and/or finished goods. Since organizations usually make a significant investment in inventories, the correct management of this tied-up capital provides a very important opportunity for business improvements. Under these circumstances, scientific methods for inventory decisions can be decisive to achieve a significant competitive advantage in today's business world. On the one hand, there is a wish to make large replenishment orders to get trade credit benefits and volume discounts, to reduce production costs by means of long production runs and economies of scale, and to increase sales by providing a high customer service level. On the other hand, there is a wish to keep stock levels down to avoid the risk of suffering financial difficulty as a result of low or tight liquidity and to avoid excessive costs incurred for keeping and managing large inventories. In order to balance these and other conflicting goals, novel approaches are required to provide an answer to at least the following three questions:

1. How often should the inventory status be reviewed and determined?

2. When should an order be placed?

3. How large should the order quantity be?

One way to tackle these issues is to use an inventory model as a decision-support tool. Generally speaking, inventory models are approximations or simplifications of real inventory management systems. It does not reflect every aspect of reality in a particular context. However, they can be useful for decision-making processes. Despite all the effort invested in research, there is still a lack of research on inventory management where useful endeavors may result not only in a significant improvement to companies but to society in general. The evidence supporting this is overwhelming. In the agricultural industry, for example, post-harvest losses are significant and unavoidable [1]. Roughly, one-third of food produced for human consumption is globally lost or wasted throughout the food supply chain, which is about 1.3 billion tons per year and has a negative impact on economic development and on the environment [2]. In the grocery retailing industry, perishable products within the grocery-food category account for approximately $50 \%$ of total supermarkets sales [3-5], and the losses of these kinds of products due to inventory spoilage at the retail level are susceptible to range from $5 \%$ to $22.8 \%[2,6]$. While reducing perishable inventory waste $20 \%$ can increase total store profit by $33 \%$ [7], mismanagement of perishable products can represent a major threat to the profitability of companies in the grocery retailing industry [8]. Therefore, finding suitable inventory management policies has always been of great importance to both researchers and practitioners.

The mathematical modeling of inventory systems has its roots in the Economic Order Quantity Model (EOQ) proposed by Harris [9] in 1913, which assists in determining the optimal number of units to order with a view to minimizing the total cost associated with the purchase, delivery and storage of the product. However, in the EOQ model, many of its basic assumptions are far removed from practice. When, for example, deterioration has a significant economic impact within inventory systems, the common assumption of unlimited shelf life for lot-size determination becomes very inaccurate. A challenging task for this class of items is to maintain 
product availability while avoiding excessive product loss so that effective inventory management is possible. Because achieving this effectiveness represents a formidable challenge to both academics and practitioners, the study of inventory systems dealing with deteriorating products is still one of the most important research areas that emerged from the first EOQ model.

This research aims to gain a more in-depth understanding of the state of the inventory modeling literature stream for deteriorating items. This responds to the need for evaluating what the lot-sizing theory applied for perishable products has collectively accomplished and what directions might be fruitful for future research. In general, the identification, evaluation, and interpretation of existing knowledge in literature reviews is an essential part of all kinds of research processes. This is frequently pointed out by textbooks on research methodologies [10-12], as well as methodological articles in high impact journals [13, 14]. In particular, since the last literature reviews on deteriorating inventory modeling [15-17], more than 300 papers have been recorded over the last years. This not only raises concerns about the state of art of this research stream but justifies the need to provide a starting point for research by identifying patterns, themes, and issues from the existing body of recorded documents.

Since the earliest works on deteriorating inventory modeling during the decades of the 50's and 60's [1820], many studies have been published every year. The first review on this research area was developed by Nahmias [21] in 1982. This review discussed the relevant literature dealing with the inventory problem of finding suitable ordering policies for either fixed or random lifetime items. Next, nine years later, and following the classification scheme of Silver [22], Raafat [23] reviewed the advances of deteriorating inventory literature but limited to those studies that investigated the effect of deterioration as a function of the on-hand inventory level. Then, in the year 2001, Goyal and Giri [24] extended Raafat [23] but included inventory models subject to fixed lifetime items. After that, in the year 2012, Bakker, Riezebos [15] updated Goyal and Giri [24] by providing an overview and classification very close to that of Goyal and Giri's to facilitate comparisons between them. Finally, Janssen, Claus [17] updated Bakker, Riezebos [15] by analyzing relevant papers from 2012 to 2015 and by discussing new topics. Unlike all the previous reviews mentioned, they included newsvendor and transport models. Apart from this stream of surveys, there are other works that have been reported in the literature. However, some of them only focused on specific topics of deteriorating inventory modeling [25-30], and others followed a different classification and/or analysis approach [16, 25].

In this paper, we complement and update the surveys in $[15,17,24]$. As in these works, we discuss the basic features, extensions and generalization of new reported published literature in the mathematical deteriorating inventory modeling (in our case, 167 papers from 2016 to 2018). However, our scope is broader and does not only include a classification of the new reported literature since the work of Janssen, Claus [17], but also includes a relevant sample of published papers from 2001 to 2015. To keep the scope of this research treatable, we limited ourselves to inventory models dealing with products which naturally undergo physical degradation. This includes most inventory models with fixed and random lifetime products, and even some models for seasonal products.

The remainder of this paper is organized as follows. In Section 2, we first describe the research materials and methodology utilized to search and select the papers included in our review. Next, in Section 3, we provide the different categories upon which our thorough evaluation of the selected literature is conducted. Discussions are then presented in Section 4, while conclusions and future research opportunities are given in Section 5 .

\section{Methodology and descriptive analysis}

With a view to review the body of research on deteriorating inventory models, the methodology applied in our study is based on the work of Seuring, Müller [31], which discusses the basics on how to conduct a literature review through a structural content analysis. By doing so, the following subsection contains a description of the material collection process as well as of the background of the collected material. 
To ensure the quality of selected studies, we confined our searching to only peer-reviewed research papers that were written in English and ranked with a quartile score of Q1 by either ISI or Scopus database. By means of this quality selection rule, material for our review was collected in two phases. In the first phase, we extracted a sample of 150 articles published between 2001 and 2015 from previous related reviews [15, 17]. We felt that 10 papers per year, meeting our above quality selection rule, was good enough to draw additional inferences. In the second phase, we used the Web of Science (WOS) Core Collection database for searching research papers from 2016 to 2018. The search in the WOS platform was conducted in 05/14/2019 by using the expression $T S=\left(\left(\right.\right.$ deteriorat $*$ OR perish* OR decay* OR "shelf life" OR spoil ${ }^{*}$ OR outdate* OR "waste" OR lifetime*) AND "Inventory"), and then filtering matched records by selecting all the Research Areas of the WOS that generated at least one relevant paper for this review. All selected Research Areas from the WOS database are displayed in Figure 1.

As can been seen in Figure 1, the above searching process yielded 1204 records. In our sample we do not include book chapters and data papers, so we first discarded them. Next, we scanned the title, keywords, and in some cases, the abstract to select all potential articles which develop an inventory model. Here, we were as flexible as possible, and we obtained a preliminary sample of 488 articles. Then, as was done for papers published between 2001 and 2015, we chose all papers ranked with a quartile score of Q1 by either ISI or Scopus database. This resulted in a sample of 325 papers. Last of all, we proceed to classify all the inventory models with the potential of being applied to products which naturally undergo physical degradation. As a result, we obtained a relevant sample of 167 papers published between 2016 and 2018.

Note that when executing a Topic Search in WOS $(\mathrm{TS}=\ldots)$, the search engine looks for further matches of the words entered by using an extended keywords ("keywords plus"), which is harvested from the title of indexed articles by WOS. We realized that this "keywords plus", which is unique to WOS, can change over time. Thus, users may be aware of this when executing the same topic search at different times. It is also worth noticing that we employed all the search terms in $[15,17]$. However, as is evident from Figure 1 and Table 1, there is a significant amount of unrelated studies even after limiting the search to specific research areas. In this regard, we had to discard 699 papers by scanning the reference manager files (RIS) exported from WOS database, and most of them coming from records found using the word "waste" (see Table 1).

To overcome this shortcoming in future literature reviews, along with the selected Research Areas from WOS (see Figure 1), we suggest a far better search expression that includes both all the papers selected in our final sample and all the inventory models for deteriorating items that we identified as relevant in a further examination. This search expression generates 493 records instead of 1804, and is provided as follows:

$T S=(($ deteriorat* OR perish* OR decay* OR "shelf life" OR lifetime\$ OR "expiration" OR "evaporating") NEAR/14 (product\$ OR item\$ OR produce $\$$ OR "inventory" OR "goods" OR food $\$$ OR "cost" OR "weibull" OR "storage") AND "inventory" NOT "ife cycle assessment")

In the above expression, the wildcards $(*, \$)$ represent unknown characters and are used to find inflected forms of the corresponding words. The asterisk $\left(^{*}\right)$ represents any group of characters while the dollar sign (\$) represent zero or one character. The quotation mark (" ") is used to find exact phrases. And the proximity operator NEAR/14 is used to find only records where the terms joined by the operator are within 14 words of each other. Readers are referred to the WOS core collection help for more details and tips.

Note that we did not recommend to use in the query the keywords spoil*, "waste" and outdate*. For the case of spoil* and outdate*, we found that all the relevant papers provided by these keywords search are also provided by the keywords perish* and "shelf life". And for the case of the "waste" keyword we found on closer examination that the records solely belonging to this query ( 15 of the 39 in Table 1 ) are not actually relevant for a review of deteriorating inventory models.

Table 2 shows the list of the Journals to which most of the selected articles belong, and ranked in descending order of papers published. It can be verified that these journals published $121(72.5 \%)$ of the total number of papers included in our review in the research period (2016-2018). The rest of journals with only one or two paper each are provided in Table 3 . 
Among all the journals, the International Journal of Production Economics alone accounts for 25 papers (17.5\% of all publications). Second and third are the Computers \& Industrial Engineering and the European Journal of Industrial Engineering with fifteen and fourteen papers each. There is a dominance of traditional Operations Research \& Management Science journals, but in recent years, environmental managementrelated journals have increasingly been used as a channel for publication.

\section{Main characteristics of inventory systems}

In general, inventory models can be broadly classify according to the demand and the type deterioration. Depending on the type of demand, there are deterministic inventory models or stochastic one. If the demand is deterministic, the variation of inventories over time on each inventory cycle may be affected by a prediction of a constant demand $\left(\frac{\mathrm{dI}(t)}{\mathrm{dt}}=-D_{1}\right)$, or by the combined effects of a constant demand $D_{1}$ and a fixed fraction $D_{2}$ of the instantaneous stock level $\left(\frac{\mathrm{dI}(t)}{\mathrm{dt}}=-D_{1}-D_{2} I(t)\right)$. In more elaborate inventory models, the depletion of the inventory can also occur due to a known function of demand depending on time or further depending on the selling price and/or one of various marketing parameters (e.g., selling price, frequency of advertisement, credit, and freshness of products). In turn, when the demand is uncertain, it may follow a known probability distribution, or it may be represented through an additive or multiplicative functional-form with random components. When the accuracy of the stochastic demand distribution/function is unknown, modeling a fuzzy/hybrid demand [32-35] can be useful to address this type of uncertainty.

According to Raafat [23], any stocked items restrained by any process from being used for its original intended use is known as inventory subject to deterioration or decay. This definition encompasses many different types of products. However, they have been traditionally classified into three main categories: items with fixed lifetime, items with random lifetime, and items subject to obsolescence.

Fixed lifetime refers to the best-before date (BBD) of most packaged products. Although these types of products are not usually spoiled at the end of its BBD, sellers discard them in order to follow regulations. Random lifetime refers to the uncertainty in the spoiled time of items like fresh produce. Here, the time to spoilage may be uncertain for each individual stocked item, but, in practice, or from a modeling perspective, the total amount of spoiled items within any specific interval of time may follows either a deterministic or probabilistic function. Finally, obsolescence refers to the rapid loss in value of unsold items due to the introduction of a new product or the end of a shopping season. Unlike fixed lifetime items, this type of products does not suffer physical degradation due to its own nature, and thus, they do not necessarily need to be removed from the inventory throughout their selling season. Typical examples are found in the fashion and technology industry, and almost all the industry applications of studies further investigating or extending the classic newsvendor problem.

Table 4 shows the classification of deteriorating inventory items adopted for most authors in the literature. Note that some of the most common terms used in the literature of inventory models such as "perishable items" and "random lifetime products" may be used in different context. For example, the term "perishable products" may be used for either items with fixed life time or items subject to obsolescence, and the "random lifetime" term may be utilized for models that do not necessarily consider deterioration as a stochastic or random process. As a result, for the sake of transparency, in the present review we use three categories that represent the way in which spoiled items are model or represented into the mathematical models. These categories are fixed lifetime items, constant deterioration rate, and time-varying deterioration rate.

The first category, inventory models with a known fixed lifetime, is used for products discarded in a particular point of time, i.e., when their expiration date has lapsed (e.g., 2 days, 1 week, etc.). The second category, inventory models with a constant deterioration rate, is used to those models where the variation of spoiled items at each period or instant of time $t$ is represented by a constant fraction $\theta$ of the instantaneous stock level $\left(e . g ., \frac{\mathrm{dI}(t)}{\mathrm{dt}}=-D_{1}-\vartheta \mathrm{I}(t)\right)$. The third category, inventory models with a varying deterioration rate, is 
used to discuss those models where the variation of spoiled items at each period or instant of time $t$ is represented by a non-uniform fraction over time of the instantaneous stock level $\left(e . g ., \frac{\mathrm{dI}(t)}{\mathrm{dt}}=-D_{1}-\theta(t) I(t)\right)$.

Note that papers such as $[36,37]$ that claim the inclusion of a deterioration rate following a probability distribution are classified in the second category when, in the mathematical model, the mean of a probability density function is used as a constant rate, and thus, the amount of spoiled items is the same over time. Contributions such as [38-50], in which the rate of deterioration can be reduced by investing $\xi$ monetary units in a preservation technology, are classified in the second or third category depending on the variability over time (or not) of spoiled items in the inventory $\operatorname{model}\left(\right.$ e.g.,$\frac{\mathrm{dI}(t)}{\mathrm{dt}}=-D_{1}-[\theta-m(\xi)] I(t) \rightarrow$ category $2 ; \frac{\mathrm{dI}(t)}{\mathrm{dt}}=-D_{1}-[1-m(\xi)] \theta(t) I(t) \rightarrow$ category 3$)$. Inventory models in which an item can randomly expire before or up until their maximum lifetime (uncertain lifetime) are classified in the third category due to the amount of the same item perishing at each period or instant of time $t$ explicitly varies with respect to time. Meanwhile, studies such as [51-74], in which the inventory loses value but it is not physically destroyed are classified in the first category.

Among other interactions, the assumptions or restrictions to be considered for the correct application of inventory models for deteriorating items include the lead time (negligible, constant, or with a known or unknown distribution), the inventory review policy (periodic or continuous), the existence of shortages (lost sales or backorders), the inclusion of multiple products (with complementary and/or substitute items), the production rate (finite, infinite or uncertain), the selling price (fixed, variable or uncertain), the time value of money, the number of echelons within the supply chain (closed loop supply chain, VMI, non-cooperative, etc.), a permissible delay in payments (fixed or conditioned), and the set of uncertain parameters or variables.

\section{Classification of inventory models}

In this section, 317 articles that developed an inventory model for deteriorating items are classified and analyzed. In Section 4.1, the studies published between 2001 and 2018 are classified according to the type of demand and deterioration assumed. Similarly, in Section 4.2, the different papers referenced are also classified according to the inclusion of the following characteristics: a determination of an optimal price policy, considerations of a stock-out period, the inclusion of multiple products, consideration of two warehouses, a study of two or more echelon within the supply chain, considerations of delay in payments, the inclusion of the time value of money, and the inclusion of uncertain parameters or variables.

\section{Classification according to the demand and deterioration}

Table 5 shows the type of demand and deterioration considered in the models of our sample according to the characteristics discussed in Section 3. Here, 230/317 of the papers reviewed have included a deterministic demand, and 92/317 included an uncertain demand. In addition, 153/317 considered a constant deterioration rate, $77 / 317$ considered a variable deterioration rate, and 94/317 studied deterioration with a fixed lifetime. Note that of all of the authors who considered an inventory model for deteriorating items with a fixed lifetime, 63/94 have taken an uncertain demand into account. Also note that from all authors who considered a deterministic demand, 148/230 did not include any of the marketing strategies that companies commonly use to influence demand, such as pricing, advertising, markdowns, post sales services, among others.

When marketing strategies are used to stimulate customers' consumption, the integration between marketing and inventory management decisions becomes important to maximize mutual benefits and avoid potential conflicts. Of the 230 deterministic inventory models, 82 incorporated an optimal decision for marketing strategies (pricing and others marketing dependent demand factors) in combination with an optimal inventory replenishment policy. Of these 82 models, 32 considered that the demand for an item depends on characteristics further than selling price, thus affecting marketing decisions: in [75-79], the demand rate is a function of the trade credit period offered by the retailer to their customers; in [53, 80-86], the demand rate is influenced 
by the frequency of advertisement or the promotional expenditure; in the work of [50, 86-88], the demand rate is affected by the customer service level such as the warranty period and the aftersales service expenditure; in [52-54, 56, 59, 61-64, 71, 89-94], the consumption rate depends on the product's freshness or quality of an item during the planning period. Finally, in [47, 80], customer's environmental concern affecting the demand are considered.

If environmental factors such as economic and marketing conditions change during the product life and have a significant effect on the demand, then the assumption that the demand in each period is a random variable and is independent of environmental factors apart from time will be incorrect. In such real life situations, the Markov chain approach provides a flexible alternative for modeling the demand process $[55,276,321$, $335,336,339-341,343-346]$; not only does it significantly generalize the Poisson process [55, 272, 278, 280, $281,287,290,297,303,304,307,308,316,333,338,341$ ], but it is also a convenient tool for modeling both the renewal and non-renewal demand arrivals. However, despite this fact, the Markovian assumption holds for demand processes with relatively low variation coefficients, i.e., in cases where high demand variances are observed, the non-stationary assumption does not hold in the Markovian environment because standard periods of constant length may introduce memory and generate correlated demand distributions within periods. For these cases, the models in $[8,285,286,292,310,319]$ provide a reasonable alternative. Of the inventory models with stochastic demand explicitly guiding marketing strategies, the models in [66, 67, 69, $283,289,293,300,314,325,326,328,330,334,342]$ are developed to define both a price decision and inventory control policies. In turn, the inventory models in [51, 66, 67, 69, 283, 289, 300, 302, 307] take into account that the market demand is random and sensitive to the freshness of the product, which is more assertive for deteriorating items.

From studies with varying deterioration rates and deterministic demand, in the inventory models [38, 89, $108,199-202,206,207,211,212,215,219,244,263-266]$, the deterioration rate is assumed to be a general or arbitrary function of time $\theta(t)$; in the models described in[268], the deterioration rate is studied as time proportional $\theta(t)=\theta t$; in the papers $[94,155,203,204,209,262]$ a three-parameter Weibull distribution $\theta(t)=\alpha \beta(t-\gamma)^{\beta-1}$ is included; in the models described in [87, 93, 157, 161, 205, 210, 213, $214,217,221,222,245,269,271]$, the deterioration rate follows a two Weibull distribution $\theta(t)=\alpha \beta(t)^{\beta-1}$; and in the models developed in $[76-79,154,158-160,162,218,220,246,267,270]$, the products deteriorate at a rate $\theta(t)=\frac{1}{1+m-t}$, where $m$ is the maximum lifetime at which the total on-hand inventory deteriorates. In other particular works: [245] present the deterioration rate as a function of both quality level and time, where the time-related function follows a two-parameter Weibull distribution; in [208] the time to deterioration is assumed normally distributed over time; and [255] introduce a deterioration rate depending on the time and storage temperature to which food products are exposed.

With respect to inventory models with an uncertain demand, it is interesting to note that most of these studies assumed a fixed life time, but few of them [34, 51, 55, 66-70, 73, 74, 90, 289] consider the influence of product freshness over demand. From inventory models with uncertain demand and constant deterioration, the deterioration of items in $[32,33,35,112,323-333]$ is assumed to be a constant fraction $\theta$ between $[0,1]$ from the on-hand inventory. Meanwhile, from inventory models with uncertain demand and time-varying deterioration, the product lifetime in $[282,337,339,340,343]$ is random and can be described by a discrete distribution, while the lifetime of each item in [297, 334-336, 338, 341, 344-346] has negative exponential distribution with parameter $\gamma(>0)$, which may be suitable for inventory systems where item lifetimes are typically small but occasionally have long lifetime.

In nearly all of the inventory models considering deteriorating items, the demanded items are immediately delivered to the customers from the goods in stock. However, when the items from the on-hand inventory are not delivered at the time of demand, but after some positive service time that usually is random, the inventory managers need to consider the replenishment policy as well as the effect of the formation of queues in the inventory system, in order to implement suitable control policies. Amirthakodi, Radhamani [335], Manuel, Sivakumar [344], and Yadavalli, Sivakumar [346] analyzed an inventory system with a service facility assuming that the customers arrive according to a Markovian arrival process with a product lifetime 
following an exponential distribution, but $[335,344]$ consider that the service facility has a single server, and [346] consider a multi-server perishable inventory system.

\section{Classification according to shared characteristics with other research streams}

As can be observed in Table 6, 167/317 of the models allowed a stock-out period in their models (category 1), $65 / 317$ took into account an inventory system with a permissible delay in payment (category 2 ), $82 / 317$ considered the determination of an optimal pricing policy (category 3), 77/317 studied a multi-echelon deteriorating inventory model (category 4), 44/317 developed an inventory model considering the time value of money (category 5), 30/317 studied a two-warehouse inventory model (category 6), 32/317 took into account the existence of multiple products (category 7 ), and 12/317 studied an inventory model in a fuzzy environment (category 8).

Out of the 167 investigations allowing shortages, a total of 18,31, 29, 31, 18, 18 and 4 models take into account the category $\mathrm{C} 2, \mathrm{C} 3, \mathrm{C} 4, \mathrm{C} 5, \mathrm{C} 6, \mathrm{C} 7$ and $\mathrm{C} 8$, respectively. Of the 64 investigations considering a delay in payment or prepayments, 11, 7, 15, 11, 0 and 5 models considered categories $\mathrm{C} 3, \mathrm{C} 4, \mathrm{C} 5, \mathrm{C} 6, \mathrm{C} 7$, and C8, respectively. Of the 82 studies determining a pricing policy, 20, 9, 4, 2 and 2 considered categories C4, C5, C6, C7 and C8, respectively. Of the 77 multi-echelon inventory models, 5, 5, 10, and 1 models included categories C5, C6, C7 and C8, respectively. Of the 44 models considering the effect of the time value of money, 8, 2, and 2 considered categories $\mathrm{C} 6, \mathrm{C} 7$, and $\mathrm{C} 8$, respectively. Of the 30 investigations considering two or more warehouses, 2 and 2 considered the categories $\mathrm{C} 7$ and $\mathrm{C} 8$ in the model, respectively. Finally, of 32 inventory models with multiple items, 12 papers considered category $\mathrm{C} 8$.

\section{Inventory models including a stock-out period}

When demand is higher than the previous forecast and cannot be fulfilled immediately with the inventory on hand, then there is an excess of demand, or shortages. Depending on the customer-company relationship, the excess of demand (shortage) can be lost [89, 90, 98, 99, 101, 155, 258], or the excess demand can be accumulated in different ways with an associated shortage cost. Therefore, the behavior of the inventory systems, when a stock-out period is allowed, differs from one model to another.

Of the deterministic inventory models developed in $[35,45,83,102,105,112,123,124,128,139-144,151$, $161,167,169,171,181,186,203,207-210,214,216,217,227,232,242,251,257,266,271,274]$, all of the excess of demand is willing to wait for the next replenishment (shortages are fully backlogged). In the papers $[87,119,122,144,157,160,172,201,211,213,226,227,229]$, shortages are allowed, but only a fixed fraction is backordered, and the rest is lost. Finally, the deterministic inventory models found in [40, 41, 43-46, 82, $84,85,138,146,152,166,173,176,177,185,187-189,192,194-196,205,218-222,225,228,234,241,245$, $246,250,263-265,269,270]$ consider that shortages are allowed, but the unsatisfied demand is partially backlogged depending on the waiting time until the arrival of the fresh lot.

With respect to the inventory models with uncertain demand and shortages, nearly all of the authors assumed that all of the excess demand during the stock-out period become either lost sales $[8,51,66,68,70,73,90$, 98, 272, 273, 275, 276, 278, 281, 282, 288-290, 294, 296-300, 302, 303, 306, 309-311, 313, 316, 320-322, 326, $332,335,337-340]$, or shortages that are fully backlogged $[8,35,112,278,284,286,287,295,297,308,315$, $319,321,323,325,329,341,343,347]$. However, some models with uncertain demand consider a partial backlogging rate: $[305,330,331,333]$ assume that a fixed fraction of shortages are backlogged while [328, 342] assume a waiting time function for unmet demand. Finally, inventory models considering a maximum allowable shortages constraint can be found in [280,336], and inventory models in which unmet demand during the stock-out period temporarily leave the service area and repeat or retry their request after some random time (until they find a positive stock level) is studied in $[345,346]$. In the latter case, it is important to note that, as opposed to the lost-sales and backlog cases, the company does not incur any expenditure toward lost sales or for holding unsatisfied demands. 
Wu, Ouyang [194] proposed a model for non-instantaneous deterioration of items with stock-dependent demand and in which the backlogging rate is variable and dependent on the waiting time for the next replenishment. Olsson and Tydesjö [308] described a model where demand is generated by a stationary Poisson process, but it is assumed that unmet demand is immediately backordered. Meanwhile, Dehghani and Abbasi [278] proposed a new age-based lateral-transshipment policy, which may be useful for reducing stockouts and improve performance in supply chains.

\section{Permissible delay in payment and/or prepayments}

In the traditional inventory economic order quantity model, it was tacitly assumed that the supplier is paid for the items as soon as the items are received. However, in business transactions it is observed that the supplier provides a grace period whereby purchasers can repay their debts without having to pay any interest (trade credit period) or may delay the payment beyond the permitted time, in which case interest is charged.

Inventory models in which the supplier provides a permissible delay to the buyers if and only if the order quantity is greater than or equal to a predetermined quantity $W$ can be found in [107, 108, 116, 168]. Authors who assume that there already exists a regular credit policy between the retailer and the vendor (fixed delay in payment) can be consulted in $[48,49,111,119,125,134,138,146,152,154,165,180,182,190,191,202$, 204-207, 243, 250, 257, 259, 333], whereas authors who consider a permissible delay of payments, but as a decision variable, can be found in [33, 75, 76, 78, 79, 118, 164].

The inventory models submitted in $[32,75,76,79,110,114,115,145,158,162,164,220,237,264,324$, 328] take into consideration affairs in which the supplier not only offers a fixed credit period to the retailer but the retailer also adopts the trade credit policy with his/her customer. A two-level trade credit is also considered in $[33,77,126,159,227,267,270]$ but with a partial trade credit in one or both echelon of the supply chain.

Alternatively, in the models presented in [117, 120, 129, 267], the supplier provides not only a permissible delay in payments to the customer but also a cash discount, to wit a cash discount is offered by the supplier if full payment is paid within time $M 1$ (period of cash discount); otherwise, the full payment is paid within time $M 2$ (with $M 2>M 1$ ).

Ouyang, Teng [131] and Guchhait, Maiti [230] consider situations in which a supplier also offers a partial permissible delay in payments even if the order quantity is less than a predetermined amount $W$ of units of an item. This means that if the order quantity $Q$ is less than $W$, then the retailer must pay a fraction $0 \leq \beta \leq 1$ of the total purchase costcQ when the order is filled and pay the rest, $c Q(1-\beta)$, at the end of the trade credit $M$.

Chang, Ouyang [109] consider a situation in which the supplier offers his/her customers a permissible delay in payments, $M 1$, and a price discount if the order quantity is greater than or equal to a predetermined quantity $Y$, a permissible delay in payments, $M 2$, if the order quantity is greater than or equal to a predetermined quantity $X$ (with $M 2>M 1$ ), and a trade credit period, $M 1$, if the order quantity is less than $X$ (or $Y$ ). In turn, $[122,142,160,227]$ develop an EOQ model with multiple prepayments

\section{Inventory models determining an optimal price decision}

In competitive environments, it is common to change the price of items to stimulate demand and decrease the rate of deterioration of stored commodities: in this context, it is important to define a price strategy during the horizon planning, and thus, it is important to include price decisions in the deteriorating inventory models.

The selling price as a decision variable was first considered for perishable products in 1996 by Eilon and Mallya [348]. Later, Kang and Kim [349] and Aggarwal and Jaggi [350] reformulated and extended this model to make way for further investigations in which both the selling price $[42,45,47,50,61,64,67,69,80-83$, 
$86-89,93,128,164,167,179,218,223,230,232,240,250-257,259,261,263-271,275,325,328]$ and the discounted selling price $[68,89,145,170,175,249,298,314]$ are taken into account as decision variables.

Traditionally, a common practice followed by companies is to maintain a constant price on the goods offered and apply discounts when items are close to expiry or when the demand decreases. However, applying an aged-dependent selling price strategy may be more beneficial [53, 62, 63, 289]. Inventory models considering a dynamic pricing policy are described in $[38,53,55,62,63,65,71,91,92,94,174,178,191,233,235,247$, $260,283,289,293,300,325,326,330,342]$.

In relation to the particular works in this category, new approaches for determining a pricing policy when reference price play a critical role in customer purchase decisions are proposed in [38, 47, 258], a clearance sales as a strategy to sell items approaching their expiration dates at a reduced price is studied by $\mathrm{Li}, \mathrm{Yu}$ [298], and an optimal replenishment and pricing policy for deteriorating items with heterogeneous consumer sensitivities is investigated by Herbon [64].

\section{Multi-echelon inventory models}

In the present literature reviewed, 39/77 of the inventory models that consider more than one echelon in the supply chain are restricted to interactions that occur between a supplier/producer and a buyer $[37,39,58$, $63,67,73,80,81,87,88,97,101,103,104,106,112,114,118,143,145,147,149,170,176,198,229,231$, $237,242,248,251,252,256,275,293,305,321,331,332]$. However, a supply chain involving a single-vendor and multiple buyers is studied in $[34,36,60,72,82,100,140,153,197,210,253,261,277,281,290,296$, 326,334 , while a two-level supply chain with multiple suppliers and multiple buyers is considered in [48, 95, $315,327]$.

Inventory models for a three-level supply chain can be found in $[42,49,86,90,96,98,133,135,136,148,155$, $156,312,318,333]$, and inventory models for a closed-loop supply chain (recovery system) are presented in $[34,73,149,163,261]$. Wee, Lee [149] incorporate VMI strategies for a green electronic product in a two-level supply chain. Yang, Chung [261] also consider a closed-loop supply system, but involve a single producer and multiple buyers. Meanwhile, Alamri [163] consider a recovery system in a production environment consisting of three shops: one of manufacturing new items, and the others for collecting and remanufacturing returned items.

Finally, it is worth noticing that most of the above studies addressed a coordinated policy for integrating a supply chain. However, few studies have proposed new mechanism for achieving a cooperation in a noncooperative environment $[67,73,88,133,256,281]$. Other few studies have also addressed the problem of a non-coordinated supply chain $[63,248,275]$ but in a competitive environment.

\section{Inventory models under the effect of time value of money}

The effect of the time value of money (TVM) and inflation is another important extension that makes inventory models applicable to real-life situations. It plays an important role in business, especially in countries with double-digit Gross National Product rate [351]. Table 7 shows the papers incorporating the time value of money effect into an inventory models. Note that few studies have been developed for determining an inventory policy with multiples items or in a fuzzy environment under time value of money.

Hou and Lin [232] discuss an inventory model for deteriorating items with price and stock dependent selling price in which shortages are completely backordered. Ghiami and Beullens [157] provide a Net Present Value analysis for a production-inventory system without the inventory cost parameters commonly used in this context. Meanwhile, Tat, Taleizadeh [143] study the optimal ordering policy in an inventory system considering backorders and delay in payments.

In the previous models, the inflation rate has been considered as a constant and known value. However, Mirzazadeh, Seyyed Esfahani [329] consider that the inflation changes over the time horizon, specifically, the 
inflation rate was assumed to be stochastic with known pdfs over the time horizon. Here, the demand rate is a linear function of the internal and external inflation rates, shortages are allowed and fully backlogged, and a constant fraction of the on-hand inventory deteriorates per unit time.

\section{Two or more warehouse for deteriorating inventory models}

In most of the existing inventory models for deteriorating items, it is assumed that all of the items are stored in a single warehouse (owned warehouse, OW). However, in some cases, organizations may require another storage facility (rented warehouse, RW) with better preserving facilities and ample capacity in which deterioration, costs, demand, and other parameters are different. These facilities are usually rented either to reduce the losses due to deterioration or to store excessive goods obtained at a discount price or simply to avoid inflation rate. Cases where a retailer owns two shops: one shop to sell fresh items until a particular point in time and the other shop to offer non-fresh items at a reduced price are included in this category. Twowarehouse inventory models incorporating further characteristics related to inventory systems are presented in Table 8. Notice that models considering two or more storage facilities and the time value of money are shown in Table 7.

Two-warehouse inventory models for products with imperfect quality, and thus, subject to inspection are developed in [121, 200]. Alamri and Syntetos [200] propose a new policy entitled "Allocation-In-FractionOut (AIFO)". Unlike Last-In-First-Out (LIFO) or First-In-First-Out (FIFO) dispatching policy which are commonly adopted in classical formulation of a two-warehouse inventory models, AIFO implies simultaneous consumption fractions associated with RW and OW. Jaggi, Tiwari [121] also study the effect of deterioration on two-warehouse inventory model with imperfect quality, but Alamri and Syntetos [200] assume that the percentage defective per lot reduces according to a learning curve while Jaggi, Tiwari [121] assume that each lot received contains a random proportion of defective item, an thus, the screening times of OW and RW are included as decisions variables.

Most of the studies uses a calculus-based approach for solving the proposed inventory model. However, some formulations require the use of metaheuristic due to the complexity of the mathematical model. For example, Guchhait, Maiti [230] studied the features of PSO with a genetic algorithm in a hybrid heuristic named PSGA (Particle Swarm-Genetic Algorithm) to show that this performance is better compared to the FGA (Fuzzy Genetic Algorithm) and the traditional PSGA in an inventory system with stock and selling price demand being dependent under crisp and fuzzy environments.

\section{Multi-item inventory systems}

Although in most inventory systems the assumption of a single item is not real, very few studies have been found in the literature dealing with multi-item inventory control compared to single-item models. Two or more items in combination with shortages are taken into account in $[34,35,70,99,101,102,105,123,155$, 245, 279, 284, 292, 296, 299, 311, 315, 341]. Inventory models considering an optimal price decision and multiple items can be found in $[62,223]$. Inventory models taking into account multiple products in a fuzzy environment are developed in $[35,137,245]$. And multi-item inventory models in a supply chain system can be found in $[34,72,100,101,103,127,155,296,312,315]$.

It is worth noticing that, although in recent years the volume of inventory models with multiples items has increased (23 papers between 2016 and 2018 compared with 9 papers between 2001 and 2015), most of the models only consider a different demand, perishing nature and/or cost parameters for items. Thus, the effect of multiple product competing for shared recourses (such as demand, space, etc.) is still a research area where much more work is needed. Studies considering these issues can be found in [57, 223, 236, 307].

Maity and Maiti [236] propose an inventory control system wherein multiple items are either complementary and/or substitutes, and the deterioration rate is stock dependent. In this work, an optimal inventory policy for complementary and substitute commodities is considered, but shortages are not allowed, and demand is stock 
dependent. Önal, Yenipazarli [223] develop a mathematical model with price-and displayed-stock -dependent demand under shelf-space and backroom storage capacity constraints. Claassen, Gerdessen [57] study a production planning and scheduling problem in a food processing industry where setups are usually sequencedependent. Finally, Najafi, Ahmadi [307] address a blood inventory management problem by considering all types of blood and their substitution compatibilities based on medical priorities.

\section{Inventory models with uncertain parameters}

In most inventory models with stochastic demand, the lead time is assumed to be either negligible [8, 69, $90,112,276,277,284,286,293,300,307,319,323,324,328-330,334,340,343]$, or a fixed positive constant [272-274, 279, 282, 287, 288, 290-292, 296, 297, 300, 304, 306, 308, 312, 313, 316, 322, 331, 332, 337, 340, 341]. However, there are inventory models that consider the lead time as an unknown parameter following an arbitrary distribution [336, 338], an exponential distribution [344-346] or a phase-type distribution [335]. Furthermore, although a non-negligible lead time is usually associated with a stochastic demand, few studies consider an uncertain lead time with deterministic demand $[172,176]$.

In some mathematical models with stochastic demand, the inventory is controlled explicitly with a periodic review system $[8,66,273,274,276,279,280,282,284,287,289,292,293,296,300,303,320,321,324,330$, 339 , while in others, it is controlled with a continuous review system [272, 278, 290, 297, 304, 306, 308, 309, $311,312,316,323,332,335,336,338,341,343-346]$. On one hand, among items monitored continuously, $[272,306,311,312,323,332,335,336,343-346]$ apply the traditional $(s, S)$ policy in which a same amount of product $(Q=S-s)$ is ordered every time the inventory level (on hand plus an order minus backorders) reaches the level of $s$. [278, 290,297, 308, 309, 338] use a $(S-1, S)$ ordering policy for stock replenishment in which in which a reorder for an item is placed whenever the inventory level drops by one unit either due to demand or because a perished unit. [304, 316] suggest a combined age-and-stock-based ordering policy, $(Q, r, T)$ policy, in which a replenishment order of size $Q$ is placed either when the inventory drops to $r$ or when $T$ units of time have elapsed, whichever occurs first. Finally, [341] uses the $\left(s_{i}, c_{i}, S_{i}\right)$ policy suggested by [352-354] with $s_{i}<c_{i}<S_{i}$ for multi-item inventory problems dealing with a group of items $i$ where the replenishment cost of two or more class of items is less than the total cost of individual or separate replenishments. In this policy, as the traditional $(s, S)$ policy, an order is placed by item $i$ when its inventory level falls to thereorder level $s_{i}$. However, any other item $j$ is also included in the same order if its inventory level is at or below itscan-order level, $c_{j}$.

On the other hand, among periodic inventory systems, [8, 276, 282, 284, 293, 300, 330, 339] study the determination of inventory policies myopically, that is, at the beginning of each given period, decisions are only made upon replenishment (one period at a time). From these papers: [322] uses a $(s, S)$ policy, i.e., an order is placed to raise the inventory to $S$ when the inventory level is less than, or equal to, the reorder point $s$; $[276,305,320]$ apply a base-stock policy of level $S$ in which the total inventory level at the beginning of each period is always raised to $S$; $[287,288]$ suggest a stock-level dependent ordering policy $\left(s, S, q_{\min }, Q_{\max }\right)$, which is a $(s, S)$ policy with the order quantity being restricted between $q_{\min }$ and $Q_{\max }$; and $[274,319]$ investigate a class of proportional balancing $(\mathrm{PB})$ policy that balances a proportion of expected marginal costs. Finally, papers applying an order up to a level $(R, S)$ policy in which the inventory level is observed at equal intervals of time $R$ and items are ordered to bring the inventory position to a level $S$ can be found in $[66,279,289,292,303,321,324]$, while papers investigating an age-based replenishment policy can be found in $[273,280,294,296]$. These age-based replenishment policies work similar to the traditional order-up-to level policy except that the inventory level is corrected for the estimated amount of outdating and an order is placed if this new corrected inventory level drops below the target reorder level.

Alternatively, in the development of inventory models for deteriorating items, researchers usually consider that all of the parameters and relevant data of the systems are already known or stochastic. However, in some practical applications, those assumptions are unrealistic because obtaining some of them (demand, production rate, costs coefficients, inflation, etc.) can be vague and imprecise or even impossible to determine exactly. In this regard, with the exception of $[77,98,155]$, nearly all of the studies $[32,35,43,77,111,119$, 
$170,183,230,239,245,255,295]$ that have investigated an inventory problem in fuzzy environments to model uncertainties in a non-stochastic sense assume that one or more parameters is a fuzzy number rather than a fuzzy variable. Note that the fuzzy variable can be interpreted as a random fuzzy variable, fuzzy random variable, fuzzy rough variable, and a hybrid variable. A fuzzy random variable can be viewed as a random variable whose values are not real but a fuzzy number, and a random fuzzy variable can be viewed as a fuzzy variable taking random variable values. The reader might refer to [355-357] for more information.

\section{Conclusions}

This paper has discussed the key characteristic of inventory systems that have been addressed by researchers since the year 2001. It revealed, in general, that there has been an incremental effort for representing reality using the inventory modeling approach from a theoretical point of view, but with little attention to its potential applicability. As a result, we found that the gap between theory and practice is increasingly wide, and there is an urgent need for incorporating more empirical evidence and useful guidelines for practitioners in this important research field. This recall us the famous aphorism attributed to George E. P. Box "all models are wrong, but some are useful", which highlights the importance of developing good enough models for real life applications instead of overrepresenting reality by increasing model complexity. Therefore, in general, we call for the incorporation of more empirical evidence into the modeling of inventory systems dealing with perishable products by critically evaluating the trade-off between applicability, simplicity, and level scientific technique. For a complete discussion of this three aspects on scientific modeling, we suggest [358].

Given the above concerns, it would be interesting to find out whether the same is happening for perishable products subjects to obsolescence (like electronics components and fashionable products), or even for nonperishable products. If the gap between theory and practice is also an increasingly growing phenomenon in the modeling of these types of products, then it is likely that one or more concepts within the inventory modeling framework have become "reified". According to Lane, Koka [359], reification is problematic because it threatens the validity of studies using a theoretical framework. A particular concept or construct becomes taken for granted and researchers increasingly fail to specify the assumptions that justify its use. To the inventory modeling literature, this would means that some of the modeling characteristics commonly used to represent inventory systems are being included or adapted out of context in an increasing range of papers instead of being treated as a building modeling approach that need to be constantly refined and revised. The problem created by reification, thus, can only be addressed through a systematic assessment of the literature in which the diverse interpretations and applications of the construct are investigated along with its underlying assumptions. Toward this aim, we recommend consulting [359, 360] and the references cited therein.

The literature on inventory management also suggests additional ways in which the models included in our review may be improved to obtain more suitable inventory policies. For example, in most of these models, it is assumed that the deterioration rate of perishable products is constant over time. i.e., a constant fraction of the on-hand inventory is assumed to spoil over time. Although this modeling approach was originally proposed to accurately represent the deterioration nature of volatile liquids and radioactive substances, it has also been extensively used by researchers as an approximation to represent a great variety of perishable products such as fresh produce. We agree that this modeling approach is particularly useful when the spoilage of products comes from multiple sources. However, there are still situations in which modeling a time-varying deterioration rate may produce a better profitable inventory policy. Similarly, exploring other topics of the inventory management literature may be of great importance for extending the existing literature. Such topics include the analysis of multiple substitutes and/or complementary products, the study of different demand patterns and marketing strategies for boosting demand, the inclusion of fuzzy parameters and so on. Particularly, from all these, we consider that applying Game theory to supply chain inventory models would be of great benefit to promote an effective management, given the natural competitive restriction in 
which operates company all around the world. All these topics may be explored in future research.

As in previous review papers, we also found an overuse of deterministic inventory models when compared to stochastic. Nevertheless, a deeper analysis conducted in our review for deterministic inventory models has revealed that there is still too much research needed in this research stream. For example, in Section 4.2 we showed that most of the deterministic inventory models have assumed that the demand is constant, stock-dependent or price dependent. However, the interest for modeling other factors, such as the freshness or quality of products, the advertisement effort and the customer service level, has grown in recent years. As would be anticipated, the study of such important factors affecting the demand through the use of a stochastic inventory modeling approach is still in its infancy. Also, with regards to the concern of best capturing the deterioration nature of products for determining suitable inventory policies, we have identified in Section 4.2 various interesting modeling approach than can be further explored and evaluated in future research. And not only in a deterministic inventory modeling approach but in a stochastic setting.

Another finding comes from the fact that incorporating practical insights from different but related research fields can be very beneficial for developing the state of art of a particular research stream. Accordingly, based on our analysis, we identified for each topic discussed the few works that have been developed to guide such integrated approaches. For example, even though queueing theory has been studied extensively by many authors, as far as our analysis reveals, only few studies [335, 344-346] have been address to unify into the inventory modeling this important research streams.

Finally, throughout Section 4.2 of the present study, we also unveiled various covered topics in which future research efforts may take the lead. For example, since the call for research of previous literature reviews [15, 17] to address the existence of multiple items into the inventory modeling, an increasing volume of papers have included this aspect. However, our analysis showed that the effect of complementary and substitute products on lot-size determination is still a critical research stream where more research is needed. In particular, important new challenges are expected for food supply chains in which actors, more than in other context, need to collaborate in sharing information and deciding common lot sizing strategy policies in order not only to achieve an overall profitability but to achieve a sustainable development that minimizes food waste concerns. Creating new approaches for considering sustainability concerns into the lot sizing modeling is also, from our perspective, a promising research area.

\section{References}

1. Kader, A.A. Increasing Food Availability by Reducing Postharvest Losses of Fresh Produce . 2005. International Society for Horticultural Science (ISHS), Leuven, Belgium.

2. Gustavsson, J., et al.,Global Food Losses and Food Waste: Extent Causes and Prevention.” . 2011, Food and Agriculture Organization (FAO) of the United Nations: Rome.

3. ProgressiveGrocer.Progressive Grocer's Annual Consumer Expenditures Study (CES): 70th Annual CES . 2017 [cited 2019 June 21]; Available from: https://progressivegrocer.com/2017-consumer-expenditure-studysupermarket-sales-charts.

4. FoodMarketInstitute. FMI Information Service . 2017 [cited 2019 June 21]; Available from: https://www.fmi.org/docs/default-source/facts-figures/supermarket-sales-by-department2016.pdf? sfvrsn=ea23716e_2.

5. Yang, C.-T., C.-Y. Dye, and J.-F. Ding, Optimal dynamic trade credit and preservation technology allocation for a deteriorating inventory model. Computers \& Industrial Engineering, 2015. 87 : p. 356-369.

6. Thomson, G.B., Food Date Labels and Hunger in America. Concordia Law Review, 2017.2 (1): p. 143-166.

7. ProfitImprovementExperts. The 2011 Retail Profit Protection Report . 2011; Available from: https://theprofitexperts.co.uk/wp-content/uploads/2011/02/RPP_REPORT.pdf. 
8. Chao, X., et al.,Approximation Algorithms for Perishable Inventory Systems.Operations Research, 2015. 63 (3): p. 585-601.

9. Harris, F.W., How Many Parts to Make at Once. Operations Research, 1990. 38 (6): p. 947-950.

10. Brewerton, P.M. and L.J. Millward, Organizational Research Methods: A Guide for Students and Researchers . First ed. 2001: SAGE Publications Ltd. 216.

11. Easterby-Smith, M., R. Thorpe, and P. Jackson, Management and Business Research 5th ed. 2015: Sage Publications Ltd. 400.

12. Saunders, M.N.K., A. Thornhill, and P. Lewis, Research Methods for Business Students . 5th ed. 2009: Prentice Hall. 656.

13. Eisenhardt, K.M., Building Theories from Case Study Research. The Academy of Management Review, 1989. 14 (4): p. 532-550.

14. Mentzer, J.T. and K.B. Kahn, A framework of logistics research. Journal of Business Logistics, 1995. 16 (1): p. 231-250.

15. Bakker, M., J. Riezebos, and R.H. Teunter, Review of inventory systems with deterioration since 2001. European Journal of Operational Research, 2012. 221 (2): p. 275-284.

16. Chaudhary, V., R. Kulshrestha, and S. Routroy, State-of-the-art literature review on inventory models for perishable products. Journal of Advances in Management Research, 2018. 15 (3): p. 306-346.

17. Janssen, L., T. Claus, and J. Sauer, Literature review of deteriorating inventory models by key topics from 2012 to 2015. International Journal of Production Economics, 2016. 182 : p. 86-112.

18. Arrow, K.J., T. Harris, and J. Marschak, Optimal Inventory Policy. Econometrica, 1951.19 (3): p. 250272.

19. Ghare, P.M. and G.F. Schrader,A model for exponentially decaying inventory. The Journal of Industrial Engineering, 1963. 14 (5): p. 238-243.

20. Within, T.M., The theory of inventory management . 2nd ed. 1957, Princeton, NJ.

21. Nahmias, S., Perishable Inventory Theory: A Review. Operations Research, 1982. 30 (4): p. 680-708.

22. Silver, E.A., Operations Research in Inventory Management: A Review and Critique. Operations Research, 1981. 29 (4): p. 628-645.

23. Raafat, F., Survey of Literature on Continuously Deteriorating Inventory Models. Journal of the Operational Research Society, 1991. 42 (1): p. 27-37.

24. Goyal, S.K. and B.C. Giri,Recent trends in modeling of deteriorating inventory. European Journal of Operational Research, 2001. 134 (1): p. 1-16.

25. Amorim, P., et al., Managing perishability in production-distribution planning: a discussion and review. Flexible Services and Manufacturing Journal, 2013. 25 (3): p. 389-413.

26. Karaesmen, I., A. Scheller-Wolf, and B. Deniz, Managing Perishable and Aging Inventories: Review and Future Research Directions, in Planning Production and Inventories in the Extended Enterprise, K.G. Kempf, P. Keskinocak, and R. Uzsoy, Editors. 2011, Springer US. p. 393-436.

27. Osorio, A.F., S.C. Brailsford, and H.K. Smith, A structured review of quantitative models in the blood supply chain: A taxonomic framework for decision-making.International Journal of Production Research, 2015. 53 (24): p. 7191-7212.

28. Pahl, J. and S. Voß,Integrating deterioration and lifetime constraints in production and supply chain planning: A survey. European Journal of Operational Research, 2014.238 (3): p. 654-674. 
29. Pentico, D.W. and M.J. Drake, $A$ survey of deterministic models for the EOQ and EPQ with partial backordering. European Journal of Operational Research, 2011.214 (2): p. 179-198.

30. Shekarian, E., et al.,Fuzzy inventory models: A comprehensive review. Applied Soft Computing, 2017. 55 : p. 588-621.

31. Seuring, S., et al., Conducting a Literature Review - The Example of Sustainability in Supply Chains, in Research Methodologies in Supply Chain Management: In Collaboration with Magnus Westhaus, H. Kotzab, et al., Editors. 2005, Physica-Verlag HD: Heidelberg. p. 91-106.

32. Mahata, G.C. and A. Goswami, An EOQ model for deteriorating items under trade credit financing in the fuzzy sense. Production Planning \& Control, 2007.18 (8): p. 681-692.

33. Majumder, P., et al.,Application of Generalized Hukuhara derivative approach in an economic production quantity model with partial trade credit policy under fuzzy environment. Operations Research Perpsectives, 2016.3 : p. $77-91$.

34. Rahimi, M., A. Baboli, and Y. Rekik, Multi-objective inventory routing problem: A stochastic model to consider profit, service level and green criteria.Transportation Research Part E-Logistics and Transportation Review, 2017. 101 : p. 59-83.

35. Wee, H.-M., C.-C. Lo, and P.-H. Hsu, A multi-objective joint replenishment inventory model of deteriorated items in a fuzzy environment. European Journal of Operational Research, 2009. 197 (2): p. 620-631.

36. Azadeh, A., et al., A genetic algorithm-Taguchi based approach to inventory routing problem of a single perishable product with transshipment. Computers and Industrial Engineering, 2017. 104 : p. 124-133.

37. Sarkar, B., A production-inventory model with probabilistic deterioration in two-echelon supply chain management. Applied Mathematical Modelling, 2013. 37 (5): p. 3138-3151.

38. Dye, C.Y. and C.T. Yang, Optimal dynamic pricing and preservation technology investment for deteriorating products with reference price effects. Omega-International Journal of Management Science, 2016. 62 : p. $52-67$.

39. Dye, C.Y. and C.T. Yang, A note on "Coordinating a supply chain for deteriorating items with a revenue sharing and cooperative investment contract". Omega-International Journal of Management Science, 2016. 62 : p. 115-122.

40. Dye, C.-Y. and T.-P. Hsieh,An optimal replenishment policy for deteriorating items with effective investment in preservation technology. European Journal of Operational Research, 2012. 218 (1): p. 106-112.

41. Hsu, P.H., H.M. Wee, and H.M. Teng, Preservation technology investment for deteriorating inventory. International Journal of Production Economics, 2010.124 (2): p. 388-394.

42. Huang, H., Y. He, and D. Li,Pricing and inventory decisions in the food supply chain with production disruption and controllable deterioration. Journal of Cleaner Production, 2018. 180 : p. 280-296.

43. Karmakar, S., S.K. De, and A. Goswami, A pollution sensitive dense fuzzy economic production quantity model with cycle time dependent production rate. Journal of Cleaner Production, 2017. 154 : p. 139-150.

44. Lee, Y.-P. and C.-Y. Dye,An inventory model for deteriorating items under stock-dependent demand and controllable deterioration rate. Computers \& Industrial Engineering, 2012. 63 (2): p. 474-482.

45. Mishra, U., et al., An inventory model under price and stock dependent demand for controllable deterioration rate with shortages and preservation technology investment. Annals of Operations Research, 2017. 254 (1-2): p. 165-190.

46. Pal, H., S. Bardhan, and B.C. Giri, Optimal replenishment policy for non-instantaneously perishable items with preservation technology and random deterioration start time. International Journal of Management Science and Engineering Management, 2018. 13 (3): p. 188-199. 
47. Saha, S., I. Nielsen, and I. Moon, Optimal retailer investments in green operations and preservation technology for deteriorating items. Journal of Cleaner Production, 2017. 140 : p. 1514-1527.

48. Tsao, Y.C., Designing a supply chain network for deteriorating inventory under preservation effort and trade credits. International Journal of Production Research, 2016. 54 (13): p. 3837-3851.

49. Tsao, Y.C., Joint location, inventory, and preservation decisions for non-instantaneous deterioration items under delay in payments. International Journal of Systems Science, 2016.47 (3): p. 572-585.

50. Zhang, J.X., et al.,Pricing, service and preservation technology investments policy for deteriorating items under common resource constraints. Computers \& Industrial Engineering, 2016. 95 : p. 1-9.

51. Afshar-Nadjafi, B., The influence of sale announcement on the optimal policy of an inventory system with perishable items. Journal of Retailing and Consumer Services, 2016. 31 : p. 239-245.

52. Afshar-Nadjafi, B., H. Mashatzadeghan, and A. Khamseh, Time-dependent demand and utility-sensitive sale price in a retailing system. Journal of Retailing and Consumer Services, 2016. 32 : p. 171-174.

53. Avinadav, T., et al.,Dynamic pricing and promotion expenditures in an EOQ model of perishable products. Annals of Operations Research, 2017.248 (1-2): p. 75-91.

54. Caliskan Demirag, O., S. Kumar, and K.S.M. Rao, A note on inventory policies for products with residuallife-dependent demand. Applied Mathematical Modelling, 2017.43 : p. 647-658.

55. Chen, J., et al., Dynamic pricing for deteriorating products with menu cost. Omega-International Journal of Management Science, 2018. 75 : p. 13-26.

56. Chen, S.C., et al.,Inventory and shelf-space optimization for fresh produce with expiration date under freshness-and-stock-dependent demand rate.Journal of the Operational Research Society, 2016. 67 (6): p. 884-896.

57. Claassen, G.D.H., et al.,On production planning and scheduling in food processing industry: Modelling non-triangular setups and product decay. Computers \& Operations Research, 2016. 76 : p. 147-154.

58. Disney, S.M. and R.D.H. Warburton, On the Lambert $W$ function: Economic Order Quantity applications and pedagogical considerations. International Journal of Production Economics, 2012. 140 (2): p. 756-764.

59. Dobson, G., E.J. Pinker, and O. Yildiz, An EOQ model for perishable goods with age-dependent demand rate. European Journal of Operational Research, 2017.257 (1): p. 84-88.

60. Fauza, G., et al., An integrated single-vendor multi-buyer production-inventory policy for food products incorporating quality degradation. International Journal of Production Economics, 2016. 182 : p. 409-417.

61. Feng, L., Y.L. Chan, and L.E. Cárdenas-Barrón, Pricing and lot-sizing polices for perishable goods when the demand depends on selling price, displayed stocks, and expiration date. International Journal of Production Economics, 2017.185 : p. 11-20.

62. Herbon, A., Should retailers hold a perishable product having different ages? The case of a homogeneous market and multiplicative demand model. International Journal of Production Economics, 2017. 193 : p. 479-490.

63. Herbon, A., A non-cooperative game model for managing a multiple-aged expiring inventory under consumers' heterogeneity to price and time. Applied Mathematical Modelling, 2017. 51 : p. 38-57.

64. Herbon, A., Optimal Pricing and Replenishment of an Expiring Inventoried Product under Heterogeneous Consumer Sensitivities. Decision Sciences, 2018. 49 (3): p. 522-552.

65. Herbon, A. and E. Khmelnitsky, Optimal dynamic pricing and ordering of a perishable product under additive effects of price and time on demand. European Journal of Operational Research, 2017. 260 (2): p. 546-556. 
66. Hou, X., R. Haijema, and D. Liu,Display, disposal, and order policies for fresh produce with a back storage at a wholesale market. Computers and Industrial Engineering, 2017. 111 : p. 18-28.

67. Hou, X.Y. and D.C. Liu,Building fresh product supply chain cooperation in a typical wholesale market. Journal of the Operational Research Society, 2017.68 (5): p. 566-576.

68. Hu, P., S. Shum, and M. Yu,Joint Inventory and Markdown Management for Perishable Goods with Strategic Consumer Behavior. Operations Research, 2016. 64 (1): p. 118-134.

69. Kaya, O. and S.R. Ghahroodi,Inventory control and pricing for perishable products under age and price dependent stochastic demand. Mathematical Methods of Operations Research, 2018. 88 (1): p. 1-35.

70. Lee, D.S. and M.H. Tongarlak, Converting retail food waste into by-product. European Journal of Operational Research, 2017. 257 (3): p. 944-956.

71. Li, R. and J.T. Teng,Pricing and lot-sizing decisions for perishable goods when demand depends on selling price, reference price, product freshness, and displayed stocks. European Journal of Operational Research, 2018.270 (3): p. 1099-1108.

72. Ngoc, M.H. and N. Nananukul,Aggregation methodologies for perishability management in production and distribution system. European Journal of Industrial Engineering, 2017. 11 (4): p. 548-568.

73. Pan, W., et al., Order policy for emergency medicine with return uncertainty in a closed-loop supply chain. Plos One, 2018. 13 (10): p. 24.

74. Vandani, B., S.T.A. Niaki, and S. Aslanzade, Production-inventory-routing coordination with capacity and time window constraints for perishable products: Heuristic and meta heuristic algorithms. Journal of Cleaner Production, 2017.161 : p. 598-618.

75. Banu, A. and S.K. Mondal,Analysis of credit linked demand in an inventory model with varying ordering cost. SpringerPlus, 2016. 5 (1).

76. Chen, S.C. and J.T. Teng, Inventory and credit decisions for time-varying deteriorating items with upstream and down-stream trade credit financing by discounted cash flow analysis. European Journal of Operational Research, 2015. 243 (2): p. 566-575.

77. Guchhait, P., M.K. Maiti, and M. Maiti, An EOQ model of deteriorating item in imprecise environment with dynamic deterioration and credit linked demand. Applied Mathematical Modelling, 2015. 39 (21): p. 6553-6567.

78. Wang, W.-C., J.-T. Teng, and K.-R. Lou, Seller's optimal credit period and cycle time in a supply chain for deteriorating items with maximum lifetime. European Journal of Operational Research, 2014. 232 (2): p. $315-321$.

79. Wu, J., et al., Optimal credit period and lot size for deteriorating items with expiration dates under two-level trade credit financing. European Journal of Operational Research, 2014. 237 (3): p. 898-908.

80. Bai, Q., M. Chen, and L. Xu, Revenue and promotional cost-sharing contract versus two-part tariff contract in coordinating sustainable supply chain systems with deteriorating items. International Journal of Production Economics, 2017. 187 : p. 85-101.

81. Bai, Q.G., et al.,Coordinating a supply chain for deteriorating items with multi-factor-dependent demand over a finite planning horizon. Applied Mathematical Modelling, 2016. 40 (21-22): p. 9342-9361.

82. Chen, Z., Optimization of production inventory with pricing and promotion effort for a single-vendor multi-buyer system of perishable products. International Journal of Production Economics, 2018. 203 : p. 333-349. 
83. Mishra, U., Optimizing a three-rates-of-production inventory model under market selling price and advertising cost with deteriorating items. International Journal of Management Science and Engineering Management, 2018. 13 (4): p. 295-305.

84. Pal, A.K., A.K. Bhunia, and R.N. Mukherjee, Optimal lot size model for deteriorating items with demand rate dependent on displayed stock level (DSL) and partial backordering. European Journal of Operational Research, 2006.175 (2): p. 977-991.

85. Palanivel, M. and R. Uthayakumar,Finite horizon EOQ model for non-instantaneous deteriorating items with price and advertisement dependent demand and partial backlogging under inflation. International Journal of Systems Science, 2015.46 (10): p. 1762-1773.

86. Tabatabaei, S.R.M., S.J. Sadjadi, and A. Makui, Optimal pricing and marketing planning for deteriorating items. Plos One, 2017. 12 (3): p. 21.

87. Chung, C.J. and H.M. Wee,An integrated production-inventory deteriorating model for pricing policy considering imperfect production, inspection planning and warranty-period- and stock-level-dependant demand. International Journal of Systems Science, 2008. 39 (8): p. 823-837.

88. Xiao, T. and T. Xu,Coordinating price and service level decisions for a supply chain with deteriorating item under vendor managed inventory. International Journal of Production Economics, 2013. 145 (2): p. 743-752.

89. Banerjee, S. and S. Agrawal,Inventory model for deteriorating items with freshness and price dependent demand: Optimal discounting and ordering policies. Applied Mathematical Modelling, 2017. 52 : p. 53-64.

90. Ensafian, H. and S. Yaghoubi,Robust optimization model for integrated procurement, production and distribution in platelet supply chain. Transportation Research Part E-Logistics and Transportation Review, 2017. 103 : p. 32-55.

91. Herbon, A., Dynamic pricing vs. acquiring information on consumers' heterogeneous sensitivity to product freshness. International Journal of Production Research, 2014.52 (3): p. 918-933.

92. Herbon, A., E. Levner, and T.C.E. Cheng, Perishable inventory management with dynamic pricing using time-temperature indicators linked to automatic detecting devices.International Journal of Production Economics, 2014. 147 : p. 605-613.

93. Qin, Y., J. Wang, and C. Wei, Joint pricing and inventory control for fresh produce and foods with quality and physical quantity deteriorating simultaneously.International Journal of Production Economics, 2014. 152 : p. $42-48$.

94. Rabbani, M., N. Pourmohammad Zia, and H. Rafiei, Joint optimal dynamic pricing and replenishment policies for items with simultaneous quality and physical quantity deterioration. Applied Mathematics and Computation, 2016.287-288 : p. 149-160.

95. Hiassat, A., A. Diabat, and I. Rahwan, A genetic algorithm approach for location-inventory-routing problem with perishable products. Journal of Manufacturing Systems, 2017. 42 : p. 93-103.

96. Hu, W., A. Toriello, and M. Dessouky, Integrated inventory routing and freight consolidation for perishable goods. European Journal of Operational Research, 2018.271 (2): p. 548-560.

97. Onal, M., The two-level economic lot sizing problem with perishable items. Operations Research Letters, 2016. 44 (3): p. 403-408.

98. Savadkoohi, E., M. Mousazadeh, and S.A. Torabi, A possibilistic location-inventory model for multi-period perishable pharmaceutical supply chain network design.Chemical Engineering Research \& Design, 2018. 138 : p. 490-505. 
99. Sazvar, Z., et al., A novel mathematical model for a multi-period, multi-product optimal ordering problem considering expiry dates in a FEFO system. Transportation Research Part E-Logistics and Transportation Review, 2016. 93 : p. 232-261.

100. Shaabani, H. and I.N. Kamalabadi, An efficient population-based simulated annealing algorithm for the multi-product multi-retailer perishable inventory routing problem. Computers and Industrial Engineering, 2016.99 : p. 189-201.

101. Tavana, M., et al., An integrated location-inventory-routing humanitarian supply chain network with pre- and post-disaster management considerations. Socio-Economic Planning Sciences, 2018. 64 : p. 21-37.

102. Xu, Y. and B.R. Sarker,Models for a family of products with shelf life, and production and shortage costs in emerging markets. Computers \& Operations Research, 2003. 30 (6): p. 925-938.

103. Zanoni, S. and L. Zavanella,Single-vendor single-buyer with integrated transport-inventory system: Models and heuristics in the case of perishable goods.Computers \& Industrial Engineering, 2007. 52 (1): p. 107-123.

104. Zhang, Q., J. Luo, and Y. Duan,Buyer-vendor coordination for fixed lifetime product with quantity discount under finite production rate. International Journal of Systems Science, 2016. 47 (4): p. 821-834.

105. Ai, X.Y., J.L. Zhang, and L. Wang, Optimal joint replenishment policy for multiple non-instantaneous deteriorating items. International Journal of Production Research, 2017.55 (16): p. 4625-4642.

106. Chan, C.K., et al., An integrated production-inventory model for deteriorating items with consideration of optimal production rate and deterioration during delivery. International Journal of Production Economics, 2017.189 : p. 1-13.

107. Chang, C.-T., An EOQ model with deteriorating items under inflation when supplier credits linked to order quantity. International Journal of Production Economics, 2004. 88 (3): p. 307-316.

108. Chang, C.-T., L.-Y. Ouyang, and J.-T. Teng, An EOQ model for deteriorating items under supplier credits linked to ordering quantity. Applied Mathematical Modelling, 2003.27 (12): p. 983-996.

109. Chang, C.-T., et al., Optimal ordering policies for deteriorating items using a discounted cash-flow analysis when a trade credit is linked to order quantity. Computers \& Industrial Engineering, 2010. 59 (4): p. 770-777.

110. Chang, C.-T., J.-T. Teng, and M.-S. Chern, Optimal manufacturer's replenishment policies for deteriorating items in a supply chain with up-stream and down-stream trade credits. International Journal of Production Economics, 2010.127 (1): p. 197-202.

111. Chen, L.-H. and L.-Y. Ouyang,Fuzzy inventory model for deteriorating items with permissible delay in payment. Applied Mathematics and Computation, 2006.182 (1): p. 711-726.

112. Chen, W., J. Li, and X. Jin, The replenishment policy of agri-products with stochastic demand in integrated agricultural supply chains. Expert Systems with Applications, 2016. 48 : p. 55-66.

113. Chu, L.Y., V.N. Hsu, and Z.-J.M. Shen, An economic lot-sizing problem with perishable inventory and economies of scale costs: Approximation solutions and worst case analysis. Naval Research Logistics, 2005. 52 (6): p. 536-548.

114. Chung, K.-J., L. Eduardo Cárdenas-Barrón, and P.-S. Ting, An inventory model with non-instantaneous receipt and exponentially deteriorating items for an integrated three layer supply chain system under two levels of trade credit. International Journal of Production Economics, 2014.155 : p. 310-317.

115. Chung, K.-J. and T.-S. Huang, The optimal retailer's ordering policies for deteriorating items with limited storage capacity under trade credit financing.International Journal of Production Economics, 2007. 106 (1): p. $127-145$. 
116. Chung, K.-J. and J.-J. Liao,Lot-sizing decisions under trade credit depending on the ordering quantity. Computers \& Operations Research, 2004. 31 (6): p. 909-928.

117. Chung, K.-J., S.-D. Lin, and H.M. Srivastava, The complete solution procedures for the mathematical analysis of some families of optimal inventory models with order-size dependent trade credit and deterministic and constant demand. Applied Mathematics and Computation, 2012. 219 (1): p. 142-157.

118. Das, B.C., B. Das, and S.K. Mondal, Integrated supply chain model for a deteriorating item with procurement cost dependent credit period. Computers \& Industrial Engineering, 2013. 64 (3): p. 788-796.

119. De, S.K. and A. Goswami, An EOQ model with fuzzy inflation rate and fuzzy deterioration rate when a delay in payment is permissible. International Journal of Systems Science, 2006. 37 (5): p. 323-335.

120. Huang, K.-N. and J.-J. Liao, A simple method to locate the optimal solution for exponentially deteriorating items under trade credit financing. Computers \& Mathematics with Applications, 2008. 56 (4): p. 965-977.

121. Jaggi, C.K., S. Tiwari, and A. Shafi, Effect of deterioration on two-warehouse inventory model with imperfect quality. Computers and Industrial Engineering, 2015.88 : p. 378-385.

122. Lashgari, M., A.A. Taleizadeh, and S.J. Sadjadi, Ordering policies for non-instantaneous deteriorating items under hybrid partial prepayment, partial trade credit and partial backordering. Journal of the Operational Research Society, 2018. 69 (8): p. 1167-1196.

123. Li, J., T.C. Edwin Cheng, and S. Wang, Analysis of postponement strategy for perishable items by EOQ-based models. International Journal of Production Economics, 2007.107 (1): p. 31-38.

124. Li, N., et al., A Stochastic Production-Inventory Model in a Two-State Production System With Inventory Deterioration, Rework Process, and Backordering. IEEE Transactions on Systems, Man, and Cybernetics: Systems, 2017.47 (6): p. 916-926.

125. Liao, J.-J., On an EPQ model for deteriorating items under permissible delay in payments.Applied Mathematical Modelling, 2007. 31 (3): p. 393-403.

126. Liao, J.J., et al.,Lot-sizing policies for deterioration items under two-level trade credit with partial trade credit to credit-risk retailer and limited storage capacity. Mathematical Methods in the Applied Sciences, 2017.40 (6): p. 2122-2139.

127. Memisoglu, G. and H. Uster,Integrated Bioenergy Supply Chain Network Planning Problem.Transportation Science, 2016. 50 (1): p. 35-56.

128. O'Neill, B. and S. Sanni,Profit optimisation for deterministic inventory systems with linear cost. Computers and Industrial Engineering, 2018. 122 : p. 303-317.

129. Ouyang, L.Y., C.T. Chang, and J.T. Teng, An EOQ model for deteriorating items under trade credits. Journal of the Operational Research Society, 2005.56 (6): p. 719-726.

130. Ouyang, L.Y., et al., Optimal order policy in response to announced price increase for deteriorating items with limited special order quantity. International Journal of Systems Science, 2016. 47 (3): p. 718-729.

131. Ouyang, L.-Y., et al., An economic order quantity model for deteriorating items with partially permissible delay in payments linked to order quantity. European Journal of Operational Research, 2009. 194 (2): p. 418-431.

132. Palak, G., S.D. Ekşioğlu, and J. Geunes, Heuristic algorithms for inventory replenishment with perishable products and multiple transportation modes. IISE Transactions, 2018. 50 (4): p. 345-365.

133. Panda, S., N.M. Modak, and L.E. Cardenas-Barron, Coordination and benefit sharing in a three-echelon distribution channel with deteriorating product.Computers \& Industrial Engineering, 2017. 113 : p. 630-645. 
134. Pervin, M., G.C. Mahata, and S.K. Roy, An inventory model with declining demand market for deteriorating items under a trade credit policy. International Journal of Management Science and Engineering Management, 2016. 11 (4): p. 243-251.

135. Rau, H., M.Y. Wu, and H.M. Wee,Deteriorating item inventory model with shortage due to supplier in an integrated supply chain. International Journal of Systems Science, 2004. 35 (5): p. 293-303.

136. Rau, H., M.-Y. Wu, and H.-M. Wee, Integrated inventory model for deteriorating items under a multiechelon supply chain environment. International Journal of Production Economics, 2003. 86 (2): p. 155-168.

137. Roy, A., S. Kar, and M. Maiti, A deteriorating multi-item inventory model with fuzzy costs and resources based on two different defuzzification techniques. Applied Mathematical Modelling, 2008. 32 (2): p. 208-223.

138. Samii, A.B., Impact of nested inventory allocation policies in a newsvendor setting.International Journal of Production Economics, 2016. 181 : p. 247-256.

139. Sargut, F.Z. and G. Işı, Dynamic economic lot size model with perishable inventory and capacity constraints. Applied Mathematical Modelling, 2017.48 : p. 806-820.

140. Sarker, B.R. and B. Wu, Optimal models for a single-producer multi-buyer integrated system of deteriorating items with raw materials storage costs. International Journal of Advanced Manufacturing Technology, 2016. 82 (1-4): p. 49-63.

141. Tai, A.H., Y. Xie, and W.K. Ching, Inspection policy for inventory system with deteriorating products. International Journal of Production Economics, 2016.173 : p. 22-29.

142. Taleizadeh, A.A., et al.,An EOQ model for perishable product with special sale and shortage. International Journal of Production Economics, 2013.145 (1): p. 318-338.

143. Tat, R., A.A. Taleizadeh, and M. Esmaeili, Developing economic order quantity model for noninstantaneous deteriorating items in vendor-managed inventory (VMI) system. International Journal of Systems Science, 2015. 46 (7): p. 1257-1268.

144. Tavakoli, S. and A.A. Taleizadeh, An EOQ model for decaying item with full advanced payment and conditional discount. Annals of Operations Research, 2017.259 (1-2): p. 415-436.

145. Thangam, A., Optimal price discounting and lot-sizing policies for perishable items in a supply chain under advance payment scheme and two-echelon trade credits. International Journal of Production Economics, 2012.139 (2): p. 459-472.

146. Tiwari, S., et al.,Impact of trade credit and inflation on retailer's ordering policies for non-instantaneous deteriorating items in a two-warehouse environment. International Journal of Production Economics, 2016.176 : p. 154-169.

147. Tiwari, S., Y. Daryanto, and H.M. Wee, Sustainable inventory management with deteriorating and imperfect quality items considering carbon emission. Journal of Cleaner Production, 2018. 192 : p. 281-292.

148. Wang, K.-J., Y.S. Lin, and J.C.P. Yu, Optimizing inventory policy for products with time-sensitive deteriorating rates in a multi-echelon supply chain.International Journal of Production Economics, 2011. 130 (1): p. 66-76.

149. Wee, H.-M., et al.,Optimal replenishment policy for a deteriorating green product: Life cycle costing analysis. International Journal of Production Economics, 2011. 133 (2): p. 603-611.

150. Xu, X., Q. Bai, and M. Chen, A comparison of different dispatching policies in two-warehouse inventory systems for deteriorating items over a finite time horizon.Applied Mathematical Modelling, 2017. 41 : p. 359-374.

151. Yang, H.-L.,Two-warehouse inventory models for deteriorating items with shortages under inflation. European Journal of Operational Research, 2004. 157 (2): p. 344-356. 
152. Yang, H.-L. and C.-T. Chang, A two-warehouse partial backlogging inventory model for deteriorating items with permissible delay in payment under inflation. Applied Mathematical Modelling, 2013. 37 (5): p. $2717-2726$.

153. Yu, Y., Z. Wang, and L. Liang, A vendor managed inventory supply chain with deteriorating raw materials and products. International Journal of Production Economics, 2012. 136 (2): p. 266-274.

154. Chen, S.-C. and J.-T. Teng, Retailer's optimal ordering policy for deteriorating items with maximum lifetime under supplier's trade credit financing. Applied Mathematical Modelling, 2014. 38 (15-16): p. 4049-4061.

155. Dai, Z., et al., A location-inventory supply chain network model using two heuristic algorithms for perishable products with fuzzy constraints. Computers and Industrial Engineering, 2018. 119 : p. 338-352.

156. Dolgui, A., et al., Optimising integrated inventory policy for perishable items in a multi-stage supply chain. International Journal of Production Research, 2018. 56 (1-2): p. 902-925.

157. Ghiami, Y. and P. Beullens,Planning for shortages? Net Present Value analysis for a deteriorating item with partial backlogging. International Journal of Production Economics, 2016. 178 : p. 1-11.

158. Mahata, G.C. and S.K. De,Supply chain inventory model for deteriorating items with maximum lifetime and partial trade credit to credit-risk customers.International Journal of Management Science and Engineering Management, 2017. 12 (1): p. 21-32.

159. Sarkar, B., S. Saren, and L.E. Cárdenas-Barrón, An inventory model with trade-credit policy and variable deterioration for fixed lifetime products. Annals of Operations Research, 2015. 229 (1): p. 677-702.

160. Teng, J.T., et al.,Inventory lot-size policies for deteriorating items with expiration dates and advance payments. Applied Mathematical Modelling, 2016. 40 (19-20): p. 8605-8616.

161. Viji, G. and K. Karthikeyan,An economic production quantity model for three levels of production with Weibull distribution deterioration and shortage. Ain Shams Engineering Journal, 2018. 9 (4): p. 1481-1487.

162. Wu, J., et al., Inventory models for deteriorating items with maximum lifetime under downstream partial trade credits to credit-risk customers by discounted cash-flow analysis. International Journal of Production Economics, 2016.171 : p. 105-115.

163. Alamri, A.A., Theory and methodology on the global optimal solution to a General Reverse Logistics Inventory Model for deteriorating items and time-varying rates. Computers \& Industrial Engineering, 2011. 60 (2): p. 236-247.

164. Arcelus, F.J., N.H. Shah, and G. Srinivasan, Retailer's pricing, credit and inventory policies for deteriorating items in response to temporary price/credit incentives. International Journal of Production Economics, 2003.81-82 : p. 153-162.

165. Benkherouf, L. and B.H. Gilding, Optimal replenishment policies for deteriorating items and permissible delay in payments. Ima Journal of Management Mathematics, 2017. 28 (2): p. 235-243.

166. Bhunia, A.K., A.A. Shaikh, and R.K. Gupta, A study on two-warehouse partially backlogged deteriorating inventory models under inflation via particle swarm optimisation. International Journal of Systems Science, 2015.46 (6): p. 1036-1050.

167. Chen, J.-M. and L.-T. Chen,Pricing and production lot-size/scheduling with finite capacity for a deteriorating item over a finite horizon. Computers \& Operations Research, 2005. 32 (11): p. 2801-2819.

168. Chung, K.-J. and J.-J. Liao, The optimal ordering policy in a DCF analysis for deteriorating items when trade credit depends on the order quantity. International Journal of Production Economics, 2006. 100 (1): p. 116-130. 
169. Chung, K.-J. and S.-F. Tsai,Inventory systems for deteriorating items with shortages and a linear trend in demand-taking account of time value. Computers \& Operations Research, 2001. 28 (9): p. 915-934.

170. Das, K., T.K. Roy, and M. Maiti, Buyer-seller fuzzy inventory model for a deteriorating item with discount. International Journal of Systems Science, 2004.35 (8): p. 457-466.

171. Das, R. and M. Okumura, A relief ordering policy for declining demand and realized shortage cost.Journal of Humanitarian Logistics and Supply Chain Management, 2016.6 (1): p. 100-116.

172. Dey, J.K., S.K. Mondal, and M. Maiti, Two storage inventory problem with dynamic demand and interval valued lead-time over finite time horizon under inflation and time-value of money. European Journal of Operational Research, 2008.185 (1): p. 170-194.

173. Dye, C.-Y., L.-Y. Ouyang, and T.-P. Hsieh, Deterministic inventory model for deteriorating items with capacity constraint and time-proportional backlogging rate.European Journal of Operational Research, 2007. 178 (3): p. 789-807.

174. Feng, L., J.X. Zhang, and W.S. Tang, Dynamic joint pricing and production policy for perishable products. International Transactions in Operational Research, 2018.25 (6): p. 2031-2051.

175. Hsu, P.H. and H.M. Wee,Discounting decision for enterprises with high fixed cost and low variable cost. International Transactions in Operational Research, 200613 (2): p. 111-124.

176. Hsu, P.-H., H.M. Wee, and H.-M. Teng, Optimal ordering decision for deteriorating items with expiration date and uncertain lead time. Computers \& Industrial Engineering, 2007. 52 (4): p. 448-458.

177. Jaggi, C.K., A. Khanna, and P. Verma, Two-warehouse partial backlogging inventory model for deteriorating items with linear trend in demand under inflationary conditions. International Journal of Systems Science, 2011.42 (7): p. 1185-1196.

178. Kaya, O. and A.L. Polat, Coordinated pricing and inventory decisions for perishable products. Or Spectrum, 2017. 39 (2): p. 589-606.

179. Khedlekar, U.K., D. Shukla, and A. Namdeo, Pricing policy for declining demand using item preservation technology. SpringerPlus, 2016. 5 (1).

180. Liao, J.-J. and K.-N. Huang,Deterministic inventory model for deteriorating items with trade credit financing and capacity constraints. Computers \& Industrial Engineering, 2010. 59 (4): p. 611-618.

181. Lin, S.-W., Inventory models with managerial policy independent of demand. European Journal of Operational Research, 2011. 211 (3): p. 520-524.

182. Mahmoudinezhad, M., A. Mirzazadeh, and M. Ghoreishi, An integrated supply chain model for deteriorating items considering delay in payments, imperfect quality and inspection errors under inflationary conditions. Proceedings of the Institution of Mechanical Engineers, Part B: Journal of Engineering Manufacture, 2017. 231 (12): p. 2197-2210.

183. Maity, K. and M. MaitiNumerical approach of multi-objective optimal control problem in imprecise environment. Fuzzy Optimization and Decision Making, 20054 (4): p. 313-330.

184. Panda, S., S. Senapati, and M. Basu, Optimal replenishment policy for perishable seasonal products in a season with ramp-type time dependent demand. Computers \& Industrial Engineering, 2008. 54 (2): p. 301-314.

185. Skouri, K. and S. Papachristos, A continuous review inventory model, with deteriorating items, timevarying demand, linear replenishment cost, partially time-varying backlogging. Applied Mathematical Modelling, 2002. 26 (5): p. 603-617. 
186. Skouri, K. and S. Papachristos,Note on "deterministic inventory lot-size models under inflation with shortages and deterioration for fluctuating demand" by Yang et al. Naval Research Logistics, 2002 . 49 (5): p. $527-529$.

187. Skouri, K. and S. Papachristos, Optimal stopping and restarting production times for an EOQ model with deteriorating items and time-dependent partial backlogging.International Journal of Production Economics, 2003. 81-82 : p. 525-531.

188. Teng, J.T. and H.L. Yang,Deterministic economic order quantity models with partial backlogging when demand and cost are fluctuating with time. Journal of the Operational Research Society, 2004. 55 (5): p. 495-503.

189. Teng, J.-T., et al., An optimal replenishment policy for deteriorating items with time-varying demand and partial backlogging. Operations Research Letters, 2002.30 (6): p. 387-393.

190. Tiwari, S., H.M. Wee, and S. Sarkar, Lot-sizing policies for defective and deteriorating items with timedependent demand and trade credit. European Journal of Industrial Engineering, 2017. 11 (5): p. 683-703.

191. Tsao, Y.-C. and G.-J. Sheen,Dynamic pricing, promotion and replenishment policies for a deteriorating item under permissible delay in payments. Computers \& Operations Research, 2008. 35 (11): p. 3562-3580.

192. Wang, S.-P., An inventory replenishment policy for deteriorating items with shortages and partial backlogging. Computers \& Operations Research, 2002. 29 (14): p. 2043-2051.

193. Wang, T.-Y. and L.-H. Chen, A production lot size inventory model for deteriorating items with timevarying demand. International Journal of Systems Science, 2001.32 (6): p. 745-751.

194. Wu, K.-S., L.-Y. Ouyang, and C.-T. Yang, An optimal replenishment policy for non-instantaneous deteriorating items with stock-dependent demand and partial backlogging. International Journal of Production Economics, 2006.101 (2): p. 369-384.

195. Yang, H.-L., A comparison among various partial backlogging inventory lot-size models for deteriorating items on the basis of maximum profit. International Journal of Production Economics, 2005. 96 (1): p. 119-128.

196. Yang, H.-L., J.-T. Teng, and M.-S. Chern, An inventory model under inflation for deteriorating items with stock-dependent consumption rate and partial backlogging shortages. International Journal of Production Economics, 2010.123 (1): p. 8-19.

197. Yang, P.C. and H.M. Wee, A single-vendor and multiple-buyers production inventory policy for a deteriorating item. European Journal of Operational Research, 2002. 143 (3): p. 570-581.

198. Yu, J.C.P., K.J. Wang, and Y.S. Lin, Managing dual warehouses with an incentive policy for deteriorating items. International Journal of Systems Science, 2016.47 (3): p. 586-602.

199. Alamri, A.A., I. Harris, and A.A. Syntetos, Efficient inventory control for imperfect quality items. European Journal of Operational Research, 2016. 254 (1): p. 92-104.

200. Alamri, A.A. and A.A. Syntetos,Beyond LIFO and FIFO: Exploring an Allocation-In-Fraction-Out (AIFO) policy in a two-warehouse inventory model. International Journal of Production Economics, 2018. 206 : p. 33-45.

201. Balkhi, Z.T., An optimal solution of a general lot size inventory model with deteriorated and imperfect products, taking into account inflation and time value of money. International Journal of Systems Science, 2004. 35 (2): p. 87-96.

202. Balkhi, Z.T., Optimal economic ordering policy with deteriorating items under different supplier trade credits for finite horizon case. International Journal of Production Economics, 2011. 133 (1): p. 216-223. 
203. Banerjee, S. and S. Agrawal,A two-warehouse inventory model for items with three-parameter Weibull distribution deterioration, shortages and linear trend in demand. International Transactions in Operational Research, 200815 (6): p. 755-775.

204. Chakraborty, D., D.K. Jana, and T.K. Roy, Two-warehouse partial backlogging inventory model with ramp type demand rate, three-parameter Weibull distribution deterioration under inflation and permissible delay in payments.Computers and Industrial Engineering, 2018. 123 : p. 157-179.

205. Chang, H.-J. and C.-Y. Dye,An inventory model for deteriorating items with partial backlogging and permissible delay in payments. International Journal of Systems Science, 2001. 32 (3): p. 345-352.

206. Chang, H.-J., C.-H. Hung, and C.-Y. Dye, An inventory model for deteriorating items with linear trend demand under the condition of permissible delay in payments.Production Planning \& Control, 2001. 12 (3): p. 274-282.

207. Chang, H.-J., C.-H. Hung, and C.-Y. Dye, A finite time horizon inventory model with deterioration and time-value of money under the conditions of permissible delay in payments. International Journal of Systems Science, 2002. 33 (2): p. 141-151.

208. Chen, J.-M. and C.-S. Lin, An optimal replenishment model for inventory items with normally distributed deterioration. Production Planning \& Control, 2002.13 (5): p. 470-480.

209. Giri, B.C., A.K. Jalan, and K.S. Chaudhuri Economic order quantity model with Weibull deterioration distribution, shortage and ramp-type demand.International Journal of Systems Science, 200334 (4): p. 237243.

210. Goel, R., A.P. Singh, and A. Chauhan, A single perishable product from a single-producer and multiplebuyer's model for Weibull deterioration with time dependent demand and allowable shortage. International Journal of Computing Science and Mathematics, 2016. 7 (1): p. 63-75.

211. Goyal, S.K. and B.C. Giri,The production-inventory problem of a product with time varying demand, production and deterioration rates. European Journal of Operational Research, 2003.147 (3): p. 549-557.

212. Li, S., Optimal control of the production-inventory system with deteriorating items and tradable emission permits. International Journal of Systems Science, 2014. 45 (11): p. 2390-2401.

213. Pervin, M., S.K. Roy, and G.W. Weber, Analysis of inventory control model with shortage under timedependent demand and time-varying holding cost including stochastic deterioration. Annals of Operations Research, 2018. 260 (1-2): p. 437-460.

214. Prasad, K. and B. Mukherjee, Optimal inventory model under stock and time dependent demand for time varying deterioration rate with shortages. Annals of Operations Research, 2016. 243 (1-2): p. 323-334.

215. Tadj, L., M. Bounkhel, and Y. Benhadid, Optimal control of a production inventory system with deteriorating items. International Journal of Systems Science, 2006.37 (15): p. 1111-1121.

216. Tripathi, R.P. and M. Kaur, A linear time-dependent deteriorating inventory model with linearly timedependent demand rate and inflation. International Journal of Computing Science and Mathematics, 2018. 9 (4): p. 352-364.

217. Vandana and H.M. Srivastava,An inventory model for ameliorating/deteriorating items with trapezoidal demand and complete backlogging under inflation and time discounting. Mathematical Methods in the Applied Sciences, 2017.40 (8): p. 2980-2993.

218. Wu, J., et al., Optimal order quantity and selling price over a product life cycle with deterioration rate linked to expiration date. International Journal of Production Economics, 2017. 193 : p. 343-351.

219. Wu, J., et al., Two inventory systems with trapezoidal-type demand rate and time-dependent deterioration and backlogging. Expert Systems with Applications, 2016.46 : p. 367-379. 
220. Wu, J., J.T. Teng, and K. Skouri, Optimal inventory policies for deteriorating items with trapezoidal-type demand patterns and maximum lifetimes under upstream and downstream trade credits. Annals of Operations Research, 2018.264 (1-2): p. 459-476.

221. Wu, K.-S., An EOQ inventory model for items with Weibull distribution deterioration, ramp type demand rate and partial backlogging. Production Planning \& Control, 2001. 12 (8): p. 787-793.

222. Wu, K.-S., EOQ inventory model for items with Weibull distribution deterioration, time-varying demand and partial backlogging. International Journal of Systems Science, 2002. 33 (5): p. 323-329.

223. Önal, M., A. Yenipazarli, and O.E. Kundakcioglu, A mathematical model for perishable products with price- and displayed-stock-dependent demand. Computers and Industrial Engineering, 2016. 102 : p. 246-258.

224. Zhou, Y.W. and S.L. Yang,An optimal replenishment policy for items with inventory-level-dependent demand and fixed lifetime under the LIFO policy. Journal of the Operational Research Society, 2003.54 (6): p. 585-593.

225. Chang, C.-T., J.-T. Teng, and S.K. Goyal, Optimal replenishment policies for non-instantaneous deteriorating items with stock-dependent demand. International Journal of Production Economics, 2010. 123 (1): p. $62-68$.

226. Chu, P. and P.S. Chen, A note on inventory replenishment policies for deteriorating items in an exponentially declining market. Computers \& Operations Research, 200229 (13): p. 1827-1842.

227. Diabat, A., A.A. Taleizadeh, and M. Lashgari, A lot sizing model with partial downstream delayed payment, partial upstream advance payment, and partial backordering for deteriorating items. Journal of Manufacturing Systems, 2017. 45 : p. 322-342.

228. Dye, C.-Y. and L.-Y. Ouyang, An EOQ model for perishable items under stock-dependent selling rate and time-dependent partial backlogging. European Journal of Operational Research, 2005. 163 (3): p. 776-783.

229. Ghiami, Y., T. Williams, and Y. Wu, A two-echelon inventory model for a deteriorating item with stockdependent demand, partial backlogging and capacity constraints.European Journal of Operational Research, 2013. 231 (3): p. 587-597.

230. Guchhait, P., M.K. Maiti, and M. Maiti, Two storage inventory model of a deteriorating item with variable demand under partial credit period. Applied Soft Computing, 2013.13 (1): p. 428-448.

231. Hemmati, M., S.M.T. Fatemi Ghomi, and M.S. Sajadieh, Vendor managed inventory with consignment stock for supply chain with stock- and price-dependent demand. International Journal of Production Research, 2017.55 (18): p. 5225-5242.

232. Hou, K.L. and L.C. Lin, An EOQ model for deteriorating items with price- and stock-dependent selling rates under inflation and time value of money.International Journal of Systems Science, 2006. 37 (15): p. 1131-1139.

233. Hsieh, T.P. and C.Y. Dye, Optimal dynamic pricing for deteriorating items with reference price effects when inventories stimulate demand. European Journal of Operational Research, 2017. 262 (1): p. 136-150.

234. Hsieh, T.-P. and C.-Y. Dye,Optimal replenishment policy for perishable items with stock-dependent selling rate and capacity constraint. Computers \& Industrial Engineering, 2010. 59 (2): p. 251-258.

235. Lu, L., J. Zhang, and W. Tang, Optimal dynamic pricing and replenishment policy for perishable items with inventory-level-dependent demand. International Journal of Systems Science, 2016. 47 (6): p. 1480-1494.

236. Maity, K. and M. Maiti, Optimal inventory policies for deteriorating complementary and substitute items. International Journal of Systems Science, 2009.40 (3): p. 267-276. 
237. Majumder, P., U.K. Bera, and M. Maiti, An EPQ model for two-warehouse in unremitting release pattern with two-level trade credit period concerning both supplier and retailer. Applied Mathematics and Computation, 2016. 274 : p. 430-458.

238. Pando, V., et al., Optimal lot-size policy for deteriorating items with stock-dependent demand considering profit maximization. Computers and Industrial Engineering, 2018. 117 : p. 81-93.

239. Roy, A., et al., An inventory model for a deteriorating item with displayed stock dependent demand under fuzzy inflation and time discounting over a random planning horizon. Applied Mathematical Modelling, 2009. 33 (2): p. 744-759.

240. Teng, J.-T. and C.-T. Chang,Economic production quantity models for deteriorating items with priceand stock-dependent demand. Computers \& Operations Research, 2005. 32 (2): p. 297-308.

241. Tiwari, S., et al., Two-warehouse inventory model for non-instantaneous deteriorating items with stockdependent demand and inflation using particle swarm optimization. Annals of Operations Research, 2017. 254 (1-2): p. 401-423.

242. Tiwari, S., et al.,Optimal pricing and lot-sizing policy for supply chain system with deteriorating items under limited storage capacity. International Journal of Production Economics, 2018. 200 : p. 278-290.

243. Tripathi, R.P., Economic ordering policies under credit financing for deteriorating items with stockdependent demand rate using discounted cash flow approach.International Journal of Management Science and Engineering Management, 2017. 12 (2): p. 111-118.

244. Kar, S., A.K. Bhunia, and M. Maiti, Inventory of multi-deteriorating items sold from two shops under single management with constraints on space and investment.Computers \& Operations Research, 200128 (12): p. 1203-1221.

245. Mahapatra, N.K. and M. Maiti,Decision process for multiobjective, multi-item production-inventory system via interactive fuzzy satisficing technique. Computers \& Mathematics with Applications, 2005.49 (5-6): p. 805-821.

246. Sarkar, B., S. Sarkar, and W.Y. Yun, Retailer's optimal strategy for fixed lifetime products.International Journal of Machine Learning and Cybernetics, 2016.7 (1): p. 121-133.

247. Tashakkor, N., S.H. Mirmohammadi, and M. Iranpoor, Joint optimization of dynamic pricing and replenishment cycle considering variable non-instantaneous deterioration and stock-dependent demand. Computers and Industrial Engineering, 2018. 123 : p. 232-241.

248. Chintapalli, P. and J. Hazra,Stocking and quality decisions for deteriorating perishable products under competition. Journal of the Operational Research Society, 2016. 67 (4): p. 593-603.

249. Sezen, B., Expected profit approach used in discount pricing decisions for perishable products. International Journal of Retail \& Distribution Management, 2004. 32 (4/5): p. 223-229.

250. Bhunia, A.K. and A.A. Shaikh,An application of PSO in a two-warehouse inventory model for deteriorating item under permissible delay in payment with different inventory policies. Applied Mathematics and Computation, 2015.256 : p. 831-850.

251. Chen, L.T.,Buyer-supplier relationship and optimisation model in a dynamic collaborative network with shortages allowed. International Journal of Computer Integrated Manufacturing, 2017. 30 (7): p. 755-767.

252. Chen, T.H., Optimizing pricing, replenishment and rework decision for imperfect and deteriorating items in a manufacturer-retailer channel. International Journal of Production Economics, 2017. 183 : p. 539-550.

253. Chen, Z. and B.R. Sarker,Integrated production-inventory and pricing decisions for a single-manufacturer multi-retailer system of deteriorating items under JIT delivery policy. International Journal of Advanced Manufacturing Technology, 2017. 89 (5-8): p. 2099-2117. 
254. Feng, L., J. Zhang, and W. Tang, Optimal Inventory Control and Pricing of Perishable Items Without Shortages. IEEE Transactions on Automation Science and Engineering, 2016. 13 (2): p. 918-931.

255. Hsiao, H.I., et al.,Deteriorating inventory model for ready-to-eat food under fuzzy environment. International Journal of Logistics Research and Applications, 2017. 20 (6): p. 560-580.

256. Huang, H.F., Y. He, and D. Li, Coordination of pricing, inventory, and production reliability decisions in deteriorating product supply chains. International Journal of Production Research, 2018. 56 (18): p. 62016224 .

257. Jaggi, C.K., S. Tiwari, and S.K. Goel, Credit financing in economic ordering policies for noninstantaneous deteriorating items with price dependent demand and two storage facilities. Annals of Operations Research, 2017.248 (1-2): p. 253-280.

258. Liu, H., et al., Optimal purchase and inventory retrieval policies for perishable seasonal agricultural products. Omega (United Kingdom), 2018. 79 : p. 133-145.

259. Teng, J.-T., C.-T. Chang, and S.K. Goyal, Optimal pricing and ordering policy under permissible delay in payments. International Journal of Production Economics, 2005.97 (2): p. 121-129.

260. Xue, M., W. Tang, and J. Zhang, Optimal dynamic pricing for deteriorating items with reference-price effects. International Journal of Systems Science, 2016. 47 (9): p. 2022-2031.

261. Yang, P.C., et al.,Collaboration for a closed-loop deteriorating inventory supply chain with multi-retailer and price-sensitive demand. International Journal of Production Economics, 2013. 143 (2): p. 557-566.

262. Begum, R., R.R. Sahoo, and S.K. Sahu, A replenishment policy for items with price-dependent demand, time-proportional deterioration and no shortages. International Journal of Systems Science, 2012. 43 (5): p. 903-910.

263. Dye, C.-Y., Joint pricing and ordering policy for a deteriorating inventory with partial backlogging. Omega, 2007. 35 (2): p. 184-189.

264. Dye, C.-Y., A finite horizon deteriorating inventory model with two-phase pricing and time-varying demand and cost under trade credit financing using particle swarm optimization. Swarm and Evolutionary Computation, 2012.5 : p. 37-53.

265. Dye, C.-Y., T.-P. Hsieh, and L.-Y. Ouyang, Determining optimal selling price and lot size with a varying rate of deterioration and exponential partial backlogging.European Journal of Operational Research, 2007. 181 (2): p. 668-678.

266. Dye, C.-Y., L.-Y. Ouyang, and T.-P. Hsieh, Inventory and pricing strategies for deteriorating items with shortages: A discounted cash flow approach. Computers \& Industrial Engineering, 2007. 52 (1): p. 29-40.

267. Li, R., et al., Pricing and lot-sizing policies for perishable products with advance-cash-credit payments by a discounted cash-flow analysis. International Journal of Production Economics, 2017. 193 : p. 578-589.

268. Mukhopadhyay, S., R.N. Mukherjee, and K.S. Chaudhuri, Joint pricing and ordering policy for a deteriorating inventory. Computers \& Industrial Engineering, 2004.47 (4): p. 339-349.

269. Papachristos, S. and K. Skouri,An inventory model with deteriorating items, quantity discount, pricing and time-dependent partial backlogging. International Journal of Production Economics, 2003. 83 (3): p. $247-256$.

270. Tiwari, S., et al., Joint pricing and inventory model for deteriorating items with expiration dates and partial backlogging under two-level partial trade credits in supply chain. International Journal of Production Economics, 2018.200 : p. 16-36.

271. Wee, H.-M. and S.-T. Law, Replenishment and pricing policy for deteriorating items taking into account the time-value of money. International Journal of Production Economics, 2001. 71 (1-3): p. 213-220. 
272. Berk, E. and U. Gurler,Analysis of the $(Q, r)$ Inventory Model for Perishables with Positive Lead Times and Lost Sales. Operations Research, 2008.56 (5): p. 1238-1246.

273. Broekmeulen, R.A.C.M. and K.H. van Donselaar, A heuristic to manage perishable inventory with batch ordering, positive lead-times, and time-varying demand. Computers \& Operations Research, 2009. 36 (11): p. 3013-3018.

274. Chao, X.L., et al.,Approximation Algorithms for Capacitated Perishable Inventory Systems with Positive Lead Times. Management Science, 2018.64 (11): p. 5038-5061.

275. Chen, X.A., Z.Z. Wang, and H.S. Yuan, Optimal pricing for selling to a static multi-period newsvendor. Operations Research Letters, 2017. 45 (5): p. 415-420.

276. Cooper, W.L., Pathwise properties and performance bounds for a perishable inventory system. Operations Research, 200149 (3): p. 455-466.

277. Crama, Y., et al.,Stochastic Inventory Routing for Perishable Products.Transportation Science, 2018. 52 (3): p. 526-546.

278. Dehghani, M. and B. Abbasi,An age-based lateral-transshipment policy for perishable items.International Journal of Production Economics, 2018. 198 : p. 93-103.

279. Dillon, M., F. Oliveira, and B. Abbasi, A two-stage stochastic programming model for inventory management in the blood supply chain. International Journal of Production Economics, 2017. 187 : p. 27-41.

280. Duan, Q. and T.W. Liao, A new age-based replenishment policy for supply chain inventory optimization of highly perishable products. International Journal of Production Economics, 2013. 145 (2): p. 658-671.

281. Ensafian, H., S. Yaghoubi, and M.M. Yazdi, Raising quality and safety of platelet transfusion services in a patient-based integrated supply chain under uncertainty.Computers \& Chemical Engineering, 2017. 106 : p. 355-372.

282. Ferguson, M. and M.E. Ketzenberg, Information Sharing to Improve Retail Product Freshness of Perishables. Production and Operations Management, 2006.15 (1): p. 57-73.

283. Ferguson, M.E. and O. Koenigsberg, How should a firm manage deteriorating inventory? Production and Operations Management, 200916 (3): p. 306-321.

284. Frank, K.C., H.-S. Ahn, and R.Q. Zhang, Inventory policies for a make-to-order system with a perishable component and fixed ordering cost. Naval Research Logistics, 2009. 56 (2): p. 127-141.

285. Gutierrez-Alcoba, A., et al.,Accelerating an algorithm for perishable inventory control on heterogeneous platforms. Journal of Parallel and Distributed Computing, 2017. 104 : p. 12-18.

286. Gutierrez-Alcoba, A., et al., A simple heuristic for perishable item inventory control under non-stationary stochastic demand. International Journal of Production Research, 2017. 55 (7): p. 1885-1897.

287. Haijema, R., A new class of stock-level dependent ordering policies for perishables with a short maximum shelf life. International Journal of Production Economics, 2013. 143 (2): p. 434-439.

288. Haijema, R. and S. Minner,Stock-level dependent ordering of perishables: A comparison of hybrid basestock and constant order policies. International Journal of Production Economics, 2016. 181 : p. 215-225.

289. Herbon, A. and A. Ceder,Monitoring perishable inventory using quality status and predicting automatic devices under various stochastic environmental scenarios. Journal of Food Engineering, 2018. 223 : p. 236247.

290. Hosseinifard, Z. and B. Abbasi, The inventory centralization impacts on sustainability of the blood supply chain. Computers \& Operations Research, 2018.89 : p. 206-212. 
291. Janssen, L., et al., A stochastic micro-periodic age-based inventory replenishment policy for perishable goods. Transportation Research Part E-Logistics and Transportation Review, 2018. 118 : p. 445-465.

292. Janssen, L., et al.,Development and simulation analysis of a new perishable inventory model with a closing days constraint under non-stationary stochastic demand. Computers and Industrial Engineering, 2018. 118 : p. $9-22$.

293. Jia, J. and Q. Hu,Dynamic ordering and pricing for a perishable goods supply chain.Computers \& Industrial Engineering, 2011. 60 (2): p. 302-309.

294. Kara, A. and I. Dogan, Reinforcement learning approaches for specifying ordering policies of perishable inventory systems. Expert Systems with Applications, 2018. 91 : p. 150-158.

295. Katagiri, H. and H. Ishii,Fuzzy inventory problems for perishable commodities. European Journal of Operational Research, 2002138 (3): p. 545-553.

296. Kiil, K., et al.,Automatic replenishment of perishables in grocery retailing: The value of utilizing remaining shelf life information. British Food Journal, 2018. 120 (9): p. 2033-2046.

297. Kouki, C., M.Z. Babai, and S. Minner, On the benefit of dual-sourcing in managing perishable inventory. International Journal of Production Economics, 2018.204 : p. 1-17.

298. Li, Q., P. Yu, and X. Wu,Managing perishable inventories in retailing: Replenishment, clearance sales, and segregation. Operations Research, 2016.64 (6): p. 1270-1284.

299. Li, Q., P. Yu, and X. Wu,Shelf Life Extending Packaging, Inventory Control and Grocery Retailing. Production and Operations Management, 2017. 26 (7): p. 1369-1382.

300. Li, Y., B. Cheang, and A. Lim, Grocery Perishables Management. Production and Operations Management, 2012. 21 (3): p. 504-517.

301. Liu, F., Product damage and free sampling: a newsvendor model with passive and proactive selfconsumption. Journal of the Operational Research Society, 2016.67 (2): p. 198-213.

302. Lodree, E.J. and B.M. Uzochukwu, Production planning for a deteriorating item with stochastic demand and consumer choice. International Journal of Production Economics, 2008. 116 (2): p. 219-232.

303. Lowalekar, H., R. Nilakantan, and N. Ravichandran, Analysis of an order-up-to-level policy for perishables with random issuing. Journal of the Operational Research Society, 2016.67 (3): p. 483-505.

304. Lowalekar, H. and N. Ravichandran, A combined age-and-stock-based policy for ordering blood units in hospital blood banks. International Transactions in Operational Research, 2017. 24 (6): p. 1561-1586.

305. Minner, S. and S. Transchel, Order variability in perishable product supply chains. European Journal of Operational Research, 2017. 260 (1): p. 93-107.

306. Muriana, C., An EOQ model for perishable products with fixed shelf life under stochastic demand conditions. European Journal of Operational Research, 2016.255 (2): p. 388-396.

307. Najafi, M., A. Ahmadi, and H. Zolfagharinia, Blood inventory management in hospitals: Considering supply and demand uncertainty and blood transshipment possibility. Operations Research for Health Care, 2017. 15 : p. 43-56.

308. Olsson, F. and P. Tydesjö,Inventory problems with perishable items: Fixed lifetimes and backlogging. European Journal of Operational Research, 2010.202 (1): p. 131-137.

309. Pan, W., et al., Medical resource inventory model for emergency preparation with uncertain demand and stochastic occurrence time under considering different risk preferences at the airport. Plos One, 2017. 12 (9): p. 16. 
310. Pauls-Worm, K.G.J., et al., Order quantities for perishable inventory control with non-stationary demand and a fill rate constraint. International Journal of Production Economics, 2016. 181 : p. 238-246.

311. Puranam, K., et al.,Managing blood inventory with multiple independent sources of supply. European Journal of Operational Research, 2017.259 (2): p. 500-511.

312. Rafie-Majd, Z., S.H.R. Pasandideh, and B. Naderi, Modelling and solving the integrated inventorylocation-routing problem in a multi-period and multi-perishable product supply chain with uncertainty: Lagrangian relaxation algorithm. Computers and Chemical Engineering, 2018.109 : p. 9-22.

313. Rajendran, S. and A.R. Ravindran, Platelet ordering policies at hospitals using stochastic integer programming model and heuristic approaches to reduce wastage. Computers \& Industrial Engineering, 2017. 110 : p. 151-164.

314. Ramanathan, R., Stocking and discounting decisions for perishable commodities using expected profit approach. International Journal of Retail \& Distribution Management, 2006. 34 (2/3): p. 172-184.

315. Soysal, M., et al.,Modeling a green inventory routing problem for perishable products with horizontal collaboration. Computers and Operations Research, 2018.89 : p. 168-182.

316. Tekin, E., Ü. Gürler, and E. Berk, Age-based vs. stock level control policies for a perishable inventory system. European Journal of Operational Research, 2001.134 (2): p. 309-329.

317. Tsai, P.-C. and J.-Y. Huang, Two-stage replenishment policies for deteriorating items at Taiwanese convenience stores. Computers \& Operations Research, 2012.39 (2): p. 328-338.

318. Xiao, T., et al.,Ordering, wholesale pricing and lead-time decisions in a three-stage supply chain under demand uncertainty. Computers \& Industrial Engineering, 2010. 59 (4): p. 840-852.

319. Zhang, H., C. Shi, and X. Chao, Technical note - Approximation algorithms for perishable inventory systems with setup costs. Operations Research, 2016. 64 (2): p. 432-440.

320. Zhang, H.N., X.L. Chao, and C. Shi, Perishable Inventory Systems: Convexity Results for Base-Stock Policies and Learning Algorithms Under Gel loured Demand.Operations Research, 2018. 66 (5): p. 1276-1286.

321. Zhou, Q.S. and T.L. Olsen,Inventory rotation of medical supplies for emergency response.European Journal of Operational Research, 2017. 257 (3): p. 810-821.

322. Zhou, Q.S. and T.L. Olsen,Rotating the medical supplies for emergency response: A simulation based approach. International Journal of Production Economics, 2018.196 : p. 1-11.

323. Benkherouf, L., A. Boumenir, and L. Aggoun, A diffusion inventory model for deteriorating items. Applied Mathematics and Computation, 2003. 138 (1): p. 21-39.

324. De, L.N. and A. Goswami, Probabilistic EOQ model for deteriorating items under trade credit financing. International Journal of Systems Science, 2009.40 (4): p. 335-346.

325. Duan, Y., Y. Cao, and J. Huo, Optimal pricing, production, and inventory for deteriorating items under demand uncertainty: The finite horizon case. Applied Mathematical Modelling, 2018. 58 : p. 331-348.

326. Krishnan, H. and R.A. Winter,Inventory Dynamics and Supply Chain Coordination. Management Science, 2010. 56 (1): p. 141-147.

327. Lin, Y.S. and K.J. Wang, A two-stage stochastic optimization model for warehouse configuration and inventory policy of deteriorating items. Computers and Industrial Engineering, 2018. 120 : p. 83-93.

328. Maihami, R., B. Karimi, and S.M.T. Fatemi Ghomi, Effect of two-echelon trade credit on pricinginventory policy of non-instantaneous deteriorating products with probabilistic demand and deterioration functions. Annals of Operations Research, 2017. 257 (1-2): p. 237-273. 
329. Mirzazadeh, A., M.M. Seyyed Esfahani, and S.M.T. Fatemi Ghomi, An inventory model under uncertain inflationary conditions, finite production rate and inflation-dependent demand rate for deteriorating items with shortages.International Journal of Systems Science, 2009. 40 (1): p. 21-31.

330. Pang, Z., Optimal dynamic pricing and inventory control with stock deterioration and partial backordering. Operations Research Letters, 2011. 39 (5): p. 375-379.

331. Sazvar, Z., et al., A bi-objective stochastic programming model for a centralized green supply chain with deteriorating products. International Journal of Production Economics, 2014. 150 : p. 140-154.

332. Shen, D., et al.,Modelling and analysis of inventory replenishment for perishable agricultural products with buyer-seller collaboration. International Journal of Systems Science, 2011. 42 (7): p. 1207-1217.

333. Tsao, Y.C. and V.T. Linh,Supply Chain Network Designs Developed for Deteriorating Items Under Conditions of Trade Credit and Partial Backordering. Networks \& Spatial Economics, 2016. 16 (3): p. 933956.

334. Akbari Kaasgari, M., D.M. Imani, and M. Mahmoodjanloo, Optimizing a vendor managed inventory (VMI) supply chain for perishable products by considering discount: Two calibrated meta-heuristic algorithms. Computers and Industrial Engineering, 2017. 103 : p. 227-241.

335. Amirthakodi, M., V. Radhamani, and B. Sivakumar, A perishable inventory system with service facility and feedback customers. Annals of Operations Research, 2015.233 (1): p. 25-55.

336. Chakravarthy, S.R. and J.K. Daniel, A Markovian inventory system with random shelf time and back orders. Computers \& Industrial Engineering, 2004. 47 (4): p. 315-337.

337. Gaukler, G., M. Ketzenberg, and V. Salin, Establishing dynamic expiration dates for perishables: An application of RFID and sensor technology. International Journal of Production Economics, 2017. 193 : p. 617-632.

338. Kalpakam, S. and S. Shanthi, A perishable inventory system with modified $(S-1, S)$ policy and arbitrary processing times. Computers \& Operations Research, 200128 (5): p. 453-471.

339. Ketzenberg, M., J. Bloemhof, and G. Gaukler, Managing Perishables with Time and Temperature History. Production and Operations Management, 2014. 24 (1): p. 54-70.

340. Ketzenberg, M., G. Gaukler, and V. Salin, Expiration dates and order quantities for perishables.European Journal of Operational Research, 2018. 266 (2): p. 569-584.

341. Kouki, C., et al., A coordinated multi-item inventory system for perishables with random lifetime. International Journal of Production Economics, 2016.181 : p. 226-237.

342. Li, Y., S. Zhang, and J. Han,Dynamic pricing and periodic ordering for a stochastic inventory system with deteriorating items. Automatica, 2017. 76 : p. 200-213.

343. Lian, Z., L. Liu, and M.F. Neuts, A Discrete-Time Model for Common Lifetime Inventory Systems. Mathematics of Operations Research, 2005. 30 (3): p. 718-732.

344. Manuel, P., B. Sivakumar, and G. Arivarignan, A perishable inventory system with service facilities and retrial customers. Computers \& Industrial Engineering, 2008. 54 (3): p. 484-501.

345. Sivakumar, B., A perishable inventory system with retrial demands and a finite population. Journal of Computational and Applied Mathematics, 2009.224 (1): p. 29-38.

346. Yadavalli, V.S.S., et al.,A multi-server perishable inventory system with negative customer. Computers \& Industrial Engineering, 2011. 61 (2): p. 254-273.

347. Yao, X., et al.,Pre-positioning inventory and service outsourcing of relief material supply chain. International Journal of Production Research, 2018. 56 (21): p. 6859-6871. 
348. Eilon, S. and R.V. Mallya.Issuing and pricing policy of semi-perishables . inProceedings of the 4th International Conference on Operational Research . 1966. New York: Wiley-Interscience.

349. Kang, S. and I.-T. Kim, A study on the price and production level of the deteriorating inventory system. International Journal of Production Research, 1983.21 (6): p. 899-908.

350. Aggarwal, S.P. and C.K. Jaggi, Ordering policy for decaying inventory. International Journal of Systems Science, 1989. 20 (1): p. 151-155.

351. Chern, M.-S., et al.,Partial backlogging inventory lot-size models for deteriorating items with fluctuating demand under inflation. European Journal of Operational Research, 2008. 191 (1): p. 127-141.

352. Balintfy, J.L., On a Basic Class of Multi-Item Inventory Problems. Management Science, 1964.10 (2): p. 287-297.

353. Silver, E.A., A control system for coordinated inventory replenishment. International Journal of Production Research, 1974. 12 (6): p. 647-671.

354. Federgruen, A., H. Groenevelt, and H.C. Tijms, Coordinated Replenishments in a Multi-Item Inventory System with Compound Poisson Demands. Management Science, 1984. 30 (3): p. 344-357.

355. Kwakernaak, H., Fuzzy random variables -I. definitions and theorems. Information Sciences, 1978. 15 (1): p. $1-29$.

356. Liu, B., Uncertainty Theory . 2004, Springer Berlin Heidelberg.

357. Liu, B., A survey of credibility theory. Fuzzy Optimization and Decision Making, 2006.5 (4): p. 387-408.

358. Grubbstrom, R.W., Some aspects on modelling as a base for scientific recommendations.Kybernetes, 2001. $30(9 / 10)$ : p. 1126-1138.

359. Lane, P.J., B.R. Koka, and S. Pathak, The Reification of Absorptive Capacity: A Critical Review and Rejuvenation of the Construct. Academy of Management Review, 2006.31 (4): p. 833-863.

360. Thomason, B.C. and T.B. Bottomore, Making sense of reification : Alfred Schutz and constructionist theory . 1982, Atlantic Highlands: Humanities Press International. 203.

Tables

Table 1 Number of records provided by each of the keywords search used.

\begin{tabular}{lll}
\hline Query & Records within Step3 & Records within Step4 \\
\hline TS=(deteriorat* AND "inventory") & 428 & 312 \\
TS=(perish* AND "inventory") & 236 & 221 \\
TS=(lifetime* AND "inventory") & 155 & 61 \\
TS=("shelf life" AND "inventory") & 66 & 48 \\
TS=("waste" AND "inventory") & 458 & 39 \\
TS=(decay* AND "inventory") & 73 & 25 \\
TS=(spoil* AND "inventory") & 12 & 11 \\
TS=(outdate* AND "inventory") & 29 & 8 \\
\hline
\end{tabular}

Table 2 Journals publishing 121 of the 167 papers selected in the period 2016-2018.

\begin{tabular}{ll}
\hline Journal name & Number of Papers \\
\hline International Journal of Production Economics & 25 \\
Computers \& Industrial Engineering & 15 \\
European Journal of Industrial Engineering & 14
\end{tabular}




\begin{tabular}{ll}
\hline Journal name & Number of Papers \\
\hline Annals of Operations Research & 9 \\
Applied Mathematical Modelling & 8 \\
International Journal of Production Research & 7 \\
International Journal of Systems Science & 6 \\
Journal of the Operational Research Society & 6 \\
International Journal of Management Science and Engineering Management & 5 \\
Journal of Cleaner Production & 5 \\
Omega-International Journal of Management Science & 4 \\
Operations Research & 4 \\
Transportation Research Part E-Logistics and Transportation Review & 4 \\
Computers \& Operations Research & 3 \\
Expert Systems with Applications & 3 \\
Plos One & 3 \\
\hline
\end{tabular}

Table 3 Journals publishing 46 of the 167 papers selected in the period 2016-2018.

\section{Journal name}

Applied Mathematics and Computation, Computers \& Chemical Engineering, International Journal of Advanced Manufact Ain Shams Engineering Journal, Automatica, British Food Journal, Chemical Engineering Research \& Design, Decision Sci

Table 4 Common classification of deteriorating inventory items in the literature.

\begin{tabular}{|c|c|c|c|}
\hline $\begin{array}{l}\text { Inventory } \\
\text { assumption }\end{array}$ & $\begin{array}{l}\text { Inventory } \\
\text { assumption }\end{array}$ & Description & Products example \\
\hline \multirow[t]{2}{*}{ Perishable products. } & $\begin{array}{l}\text { Fixed lifetime Fixed shelf } \\
\text { life Age dependent }\end{array}$ & $\begin{array}{l}\text { During the planning } \\
\text { horizon, Products are } \\
\text { hold in stock for a } \\
\text { specified length of time, } \\
\text { after which they must be } \\
\text { removed }\end{array}$ & $\begin{array}{l}\text { Red blood cells, most } \\
\text { packaged foods, canned } \\
\text { goods, photographic film, } \\
\text { and drugs. }\end{array}$ \\
\hline & $\begin{array}{l}\text { Obsolescence Seasonal } \\
\text { items }\end{array}$ & $\begin{array}{l}\text { At the end of the } \\
\text { planning horizon (known } \\
\text { or uncertain), products } \\
\text { are abruptly reduced in } \\
\text { price or disposed off. }\end{array}$ & $\begin{array}{l}\text { Newspapers, fashion } \\
\text { clothes, electronics } \\
\text { components, maps, } \\
\text { cameras, airline tickets }\end{array}$ \\
\hline \multirow[t]{2}{*}{$\begin{array}{l}\text { Random lifetime, } \\
\text { Continuous decay, } \\
\text { Decaying products. }\end{array}$} & $\begin{array}{l}\text { Exponential decay Age } \\
\text { independent Inventory } \\
\text { dependent. }\end{array}$ & $\begin{array}{l}\text { A fixed fraction of the } \\
\text { inventory is lost each } \\
\text { period regardless of its } \\
\text { age distribution, or } \\
\text { lifetime of individual } \\
\text { units is an exponential } \\
\text { random variable }\end{array}$ & $\begin{array}{l}\text { Fresh produce Volatile } \\
\text { liquids such as gasoline, } \\
\text { alcohol, and acetone } \\
\text { Radioactive substances } \\
\text { such as } \\
\text { radiopharmaceuticals. }\end{array}$ \\
\hline & Age independent & $\begin{array}{l}\text { Lifetime of units is a } \\
\text { random variable } \\
\text { following a probability } \\
\text { distribution. }\end{array}$ & \\
\hline
\end{tabular}




\begin{tabular}{llll}
\hline $\begin{array}{l}\text { Inventory } \\
\text { assumption }\end{array}$ & $\begin{array}{l}\text { Inventory } \\
\text { assumption }\end{array}$ & Description & Products example \\
\hline Time dependent & $\begin{array}{l}\text { The deterioration of } \\
\text { the inventory is a } \\
\text { discretely or } \\
\text { continuously function } \\
\text { of time. }\end{array}$ \\
& & \\
\hline
\end{tabular}

Table 5 Classification according to the demand and deterioration rate (2001-2018).

\begin{tabular}{lll}
\hline Demand & Fixed lifetime & Constant deterioration over time \\
\hline Constant & {$[57,58,60,72,73,95-104]$} & {$[32,36,37,40,41,43,46,48,49,105-153]$} \\
Time dependent & {$[52,57,65,72,95-100]$} & {$[36,80,81,113,127,132,134,139,163-19$} \\
stock dependent & {$[56,61,71,223,224]$} & {$[35,44,45,84,194,196,225-243]$} \\
Price dependent & {$[53,61-65,71,91,92,223,248,249]$} & {$[39,42,45,47,50,80-86,88,128,164,167$} \\
Function of other marketing factors & {$[52-54,56,59,61-64,71,90-92]$} & {$[47,50,75,80-86,88]$} \\
Uncertain & {$[8,34,51,55,66-70,73,74,90,272-322]$} & {$[32,33,35,112,323-333]$} \\
\hline
\end{tabular}

Table 6 Classification of papers per category (2001-2014).

\begin{tabular}{|c|c|}
\hline Category & Known demand \\
\hline ing a stock-out period & 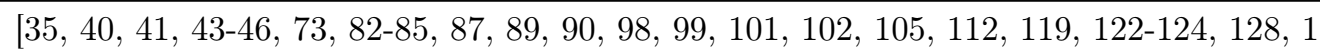 \\
\hline C2.Delay & 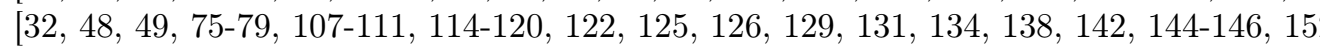 \\
\hline C3.Optimal price decisions & {$[38,42,45,47,50,53,61-65,71,80-83,86-89,91-94,128,145,164,167,170,174,175$} \\
\hline C4.Multi-echelon inventory models & {$[36,37,39,42,48,49,58,60,63,72,73,80-82,86-88,90,95-98,100,101,103,104,10$} \\
\hline C5.Time value of money & {$[76,85,87,107,109,119,138,143,146,151,157,162,166,168,169,172,177,182,18$} \\
\hline C6.Two or more warehou & {$[99,115,121,126,138,146,151,152,166,172,173,177,180,198,200,203,204,229$, } \\
\hline C7.Inclusion of multiple items & {$[35,57,62,72,99-103,105,123,127,132,137,155,223,236,244,245]$} \\
\hline C8.Fuzzy environment & {$[32,35,77,111,119,137,170,183,230,239,245,295]$} \\
\hline
\end{tabular}

Table 7 Inventory models considering TVM and other factors.

\begin{tabular}{ll}
\hline Features & References \\
\hline Shortages & {$[85,87,119,138,143,146,151,157,166,169,172,177,186,196,201,207,208,217,219,220,232,2$} \\
Delay in payments & {$[76,107,109,119,138,146,162,168,182,202,204,207,220,243,267]$} \\
Price decision & {$[87,232,266,267,271,283,293,326,330]$} \\
Multi-echelon & {$[87,143,293,321,326]$} \\
Two-warehouse & {$[138,146,151,166,172,177,204,241]$} \\
Multiple items & {$[284,311]$} \\
Fuzzy environments & {$[119,239]$} \\
\hline
\end{tabular}

Table 8 Inventory models considering two or more warehouses and other factors.

\begin{tabular}{ll}
\hline Features & References \\
\hline Shortages & {$[66,99,138,146,151,152,166,172,173,177,203,229,241,242,250,257,278,322]$}
\end{tabular}




\begin{tabular}{ll}
\hline Features & References \\
\hline Delay in payments & {$[115,126,138,146,152,180,204,230,237,250,257]$} \\
Price decision & {$[230,235,250,257]$} \\
Multi-echelon & {$[198,229,237,242,327]$} \\
Multiple-items & {$[99,244]$} \\
Fuzzy environments & {$[230]$} \\
\hline
\end{tabular}

Figure Legends

Figure 1 Review methodology for published papers during 2016-2018.

Step1: WOS Topic Search

$\mathrm{TS}=(($ deteriorat* OR perish* OR decay* OR "shelf life" OR spoil* OR outdate* OR "waste" OR lifetime*) AND "inventory")

TIMESPAN=2016-2018 AND LANGUAGE: (English) AND DOCUMENT TYPES: (Article)

Step2: Limit to (Research Areas)
1804 papers
SU=(Agriculture OR Environmental Sciences \& Ecology OR Food Science \& Technology
OR Health Care Sciences \& Services OR Hematology OR Pharmacology \& Pharmacy OR
Public, Environmental \& Occupational Health OR Mathematics OR Business \&
Economics OR Mathematical Methods In Social Sciences OR Social Sciences Other
Topics OR Automation \& Control Systems OR Computer Science OR Engineering OR
Information Science \& Library Science OR Operations Research \& Management Science
OR Science \& Technologv Other Topics OR Transportation)

$\sqrt{1204 \text { papers }} \square$

Step3: Additional excluded document types

Book chapters (16) and data papers (1)

$\sqrt{1187 \text { papers } \quad \square}$

Step4: Scan of RIS files

Scanning title, keywords, and if necessary, the abstract to select all potential inventory models.

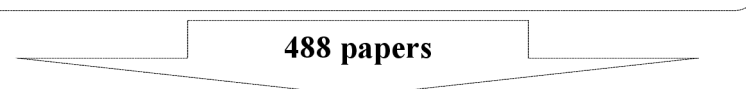

\section{Step5: Q1 (ISI or Scopus)}

Journals Ranked with a quartile score of Q1 by either ISI or Scopus database.
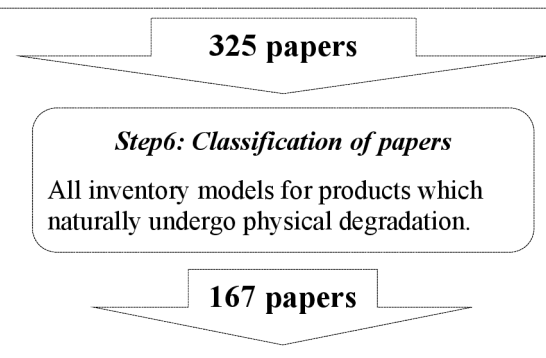